\title{
Spatial and temporal variability of the dimethylsulfide to chlorophyll ratio in the surface ocean: an assessment based on phytoplankton group dominance determined from space
}

\author{
I. Masotti ${ }^{1}$, S. Belviso ${ }^{1}$, S. Alvain ${ }^{2}$, J. E. Johnson ${ }^{3}$, T. S. Bates ${ }^{4}$, P. D. Tortell ${ }^{5}$, N. Kasamatsu ${ }^{6}$, M. Mongin ${ }^{7}$, \\ C. A. Marandino ${ }^{8}$, E. S. Saltzman ${ }^{9}$, and C. Moulin ${ }^{1}$ \\ ${ }^{1}$ Laboratoire des Sciences du Climat et de l'Environnement, IPSL-CEA-CNRS-UVSQ, CEA/Saclay, UMR 8212, \\ Orme des Merisiers, Bat 712, 91191 Gif sur Yvette, France \\ ${ }^{2}$ Univ Lille Nord de France, ULCO-LOG, CNRS, UMR 8187, 62930 Wimereux, France \\ ${ }^{3}$ Joint Institute for the Study of the Atmosphere and Ocean, University of Washington, Seattle, WA, USA \\ ${ }^{4}$ Pacific Marine Environmental Laboratory, NOAA, Seattle, WA, USA \\ ${ }^{5}$ Department of Earth and Ocean Sciences, University of British Columbia, Vancouver, Canada \\ ${ }^{6}$ National Institute of Polar Research, Tokyo, Japan \\ ${ }^{7}$ CSIRO Marine and Atmospheric Research, Hobart, Australia \\ ${ }^{8}$ Leibniz-Institute of Marine Sciences (IFM-GEOMAR), Kiel, Germany \\ ${ }^{9}$ University of California, Irvine, CA 92697-3100, USA
}

Received: 16 April 2010 - Published in Biogeosciences Discuss.: 20 May 2010

Revised: 30 August 2010 - Accepted: 30 September 2010 - Published: 20 October 2010

\begin{abstract}
Dimethylsulfoniopropionate (DMSP) is produced in surface seawater by phytoplankton. Phytoplankton culture experiments have shown that nanoeucaryotes (NANO) display much higher mean DMSP-to-Carbon or DMSP-toChlorophyll (Chl) ratios than Prochlorococcus (PRO), Synechococcus (SYN) or diatoms (DIAT). Moreover, the DMSPlyase activity of algae which cleaves DMSP into dimethylsulfide (DMS) is even more group specific than DMSP itself. Ship-based observations have shown at limited spatial scales, that sea surface DMS-to-Chl ratios (DMS:Chl) are dependent on the composition of phytoplankton groups. Here we use satellite remote sensing of $\mathrm{Chl}$ (from SeaWiFS) and of Phytoplankton Group Dominance (PGD from PHYSAT) with shipbased sea surface DMS concentrations ( 8 cruises in total) to assess this dependence on an unprecedented spatial scale. PHYSAT provides PGD (either NANO, PRO, SYN, DIAT, Phaeocystis (PHAEO) or coccolithophores (COC)) in each satellite pixel ( $1 / 4^{\circ}$ horizontal resolution). While there are identification errors in the PHYSAT method, it is important
\end{abstract}

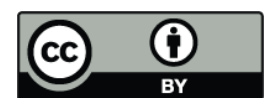

Correspondence to: I. Masotti (italo.masotti@1sce.ipsl.fr) to note that these errors are lowest for NANO PGD which we typify by high DMSP:Chl. In summer, in the Indian sector of the Southern Ocean, we find that mean DMS:Chl associated with $\mathrm{NANO}+\mathrm{PHAEO}$ and $\mathrm{PRO}+\mathrm{SYN}+\mathrm{DIAT}$ are $13.6 \pm 8.4 \mathrm{mmol} \mathrm{g}^{-1}(n=34)$ and $7.3 \pm 4.8 \mathrm{mmol} \mathrm{g}^{-1}(n=$ $24)$, respectively. That is a statistically significant difference $(P<0.001)$ that is consistent with NANO and PHAEO being relatively high DMSP producers. However, in the western North Atlantic between $40^{\circ} \mathrm{N}$ and $60^{\circ} \mathrm{N}$, we find no significant difference between the same PGD. This is most likely because coccolithophores account for the non-dominant part of the summer phytoplankton assemblages. Meridional distributions at $22^{\circ} \mathrm{W}$ in the Atlantic, and $95^{\circ} \mathrm{W}$ and $110^{\circ} \mathrm{W}$ in the Pacific, both show a marked drop in DMS:Chl near the equator, down to few mmol $\mathrm{g}^{-1}$, yet the basins exhibit different PGD (NANO in the Atlantic, PRO and SYN in the Pacific). In tropical and subtropical Atlantic and Pacific waters away from the equatorial and coastal upwelling, mean DMS:Chl associated with high and low DMSP producers are statistically significantly different, but the difference is opposite of that expected from culture experiments. Hence, in a majority of cases PGD is not of primary importance in

Published by Copernicus Publications on behalf of the European Geosciences Union. 
controlling DMS:Chl variations. We therefore conclude that water-leaving radiance spectra obtained simultaneously from ocean color sensor measurements of $\mathrm{Chl}$ concentrations and dominant phytoplankton groups can not be used to predict global fields of DMS.

\section{Introduction}

Charlson et al. (1987) proposed a potential climate feedback involving DMS emissions, aerosols, and cloud albedo. In a recent review paper of natural aerosol interactions and feedbacks within the Earth system, Carslaw et al. (2010) show that there is still ambiguity in the sign of this climate feedback. Indeed, predictions of the direct and indirect aerosol forcing due to changes in DMS emissions by year 2100 lies between -0.125 and $+0.25 \mathrm{~W} \mathrm{~m}^{-2}$. This range was calculated from five independent simulations based on empirical surface ocean DMS concentration parameterizations or mechanistic models (Carslaw et al., 2010). The use of empirical marine DMS parameterizations for projections of future climate has recently been questioned by Halloran et al. (2010). The authors highlighted the danger of including poorly understood components, such as any type of empirical parameterizations, into earth-systems models. Although the authors specifically examined only two DMS empirical relationships that they qualified as being similarly valid, they suggested that many of their conclusions were applicable to other DMS schemes (e.g. Bopp et al., 2003; Vallina et al., 2007). Unconsistent with the conclusions of Halloran et al. (2010), the first intercomparison of global climatological maps of sea surface DMS indicated that five different empirical DMS parameterizations exhibited varying levels of agreement with independent present day in situ data, depending on the critical parameters used (Belviso et al., 2004). In the diagnostic DMS model of Vallina et al. (2007), the critical parameters are irradiance and mixed layer depth whereas in the study of Bopp et al. (2003) the controlling parameter is the community structure of marine phytoplankton. These diagnostic models are so conceptually different that it is hard to believe that they will reproduce present day seawater DMS concentrations with the same degree of skill as suggested by Halloran et al. (2010). Clearly, tools are needed to evaluate global emissions of DMS to the atmosphere and refine the current parameterizations.

Attempts to correlate DMS concentrations to chlorophyll (Chl) have not proven robust likely because (1) Chl and DMS vary on different time scales, days and hours respectively, and (2) the cycle of DMS in seawater is controlled by a number of complex physical, chemical and biological processes (Kettle et al., 1999; Stefels et al., 2007; Vogt and Liss, 2009). Nevertheless, one of the most important controls on DMS production appears to be the combination of phytoplankton species composition and zooplankton grazing (see Table 6 in Stefels et al., 2007). Microzooplankton grazing of prokaryotic picoplankton (cyanophytes and prochlorophytes) is expected to yield no DMS since this algal group produces almost no dimethylsulfoniopropionate (DMSP, the major precursor of DMS) and displays no DMSP-lyase activity to catalyze the conversion of DMSP to DMS. In contrast, zooplankton grazing of phytoflagellates, including the bloom-forming Phaeocystis and high-lyase Emiliania huxleyi strains, strongly stimulates DMS production. In addition to these taxonomic effects, the physiological condition of algal cells also influences the DMS and DMSP production of phytoplankton (Sunda et al., 2007 and references therein). Diatoms which typically are low DMSP-containing algae (Keller et al., 1989), respond to nitrogen limitation by markedly increasing their DMSP cell content (Bucciarelli and Sunda, 2003; Sunda et al., 2007). Instead, nitrogenlimitation of the coccolithophore Emiliania huxleyi, which has a constitutively high intracellular DMSP concentration, increases the activity of the DMSP cleavage enzyme and DMS production but not that of DMSP (Sunda et al., 2007). In a first attempt to evaluate the importance of phytoplankton taxonomic composition on the spatial and temporal distribution of DMS around mainland Britain, Turner et al. (1988) identified, enumerated and converted to carbon biomass each particular group or species of phytoplankton. Then they investigated the relationship between DMS and Chl concentrations for samples containing an identifiable dominant group. They identified coccolithophores and various dinoflagellates as major DMS sources. A similar approach was deployed by Malin et al. (1993) in the northeast Atlantic during the summer coccolithophore bloom. Statistically significant correlations between particulate DMSP and Chl were found for samples from areas where coccolithophores accounted for $50 \%$ or more of the total carbon biomass. Correlations between DMS and Chl were not as strong but still significant. However, no clear relationship was found in the Barents Sea between the percent contribution of Phaeocystis pouchetii to the total pool of phytoplanktonic carbon and DMS:Chl sea surface variations (Matrai and Vernet, 1997). Hence, the role that species composition plays in controlling DMS concentrations in the ocean remains elusive because of the difficulty in accessing phytoplankton speciation with a spatial and temporal resolution comparable to that of sea surface $\mathrm{Chl}$ or DMS concentrations (Kettle et al., 1999).

Modeling studies suggest a close link between DMS:Chl and dominant phytoplankton groups. The PISCES and PlankTOM5 3-D biogeochemical prognostic models simulate marine biological productivity and describe the biogeochemical cycles of carbon, macro and micro nutrients, and several phytoplankton and zooplankton functional groups. Prognostic modules computing DMS concentrations and DMS air-sea fluxes are imbedded within PISCES and PlankTOM5 (Bopp et al., 2008; Vogt et al., 2010). DMSP cell quota are taken in both models from Stefels et al. (2007) after Keller et al. (1989), in order to compute particulate 
DMSP from the carbon biomass of two or three phytoplankton groups (nanophytoplankton, coccolithophores and diatoms). The DMSP cell quota of diatoms is 5-6 times lower than that of other groups (Stefels et al., 2007). The modules also simulate bacterial activity which transforms DMSP into DMS as a function of bacterial nutrient stress as per Kiene et al. (2000). DMS is then removed by ventilation, mixing, bacterial consumption and photodegradation. Figure $\mathrm{S} 1$ shows the spatial and seasonal variability of mean DMS:Chl computed by both models sorted according to phytoplankton dominance. A phytoplankton functional type is considered to be dominant when its contribution to the total phytoplankton carbon biomass is greater than $60 \%$. In the PISCES model, the response to group dominance is obvious since mean DMS:Chl are 5-6 times higher in NANOthan in DIAT-dominated waters during the summer season in both hemispheres (Fig. S1a). The difference is much less during winter because there are pixels exhibiting lower ratios in NANO- than in DIAT-dominated areas (data not show but as error bars and median values in Fig. S1a suggest). In PlankTOM5, mean values of DMS:Chl in NANO-dominated areas are significantly higher (about 2-fold) than in DIATdominated ones in December, but not in August (Fig. S1b). The role devoted to NANO in the control of DMS:Chl highs in PISCES is transferred to COC in PlankTOM5. Hence the outputs of two state-of-the-art 3-D models including DMS modules show that when the dominant phytoplankton group is NANO or COC, these groups appear to be responsible for the highest relative sea surface accumulation of DMS. Does phytoplankton group dominance play such a pivotal role in the global ocean as it does in 3-D models?

The detection of the dominant phytoplankton groups in marine surface waters from space is now possible using the PHYSAT algorithm (Alvain et al., 2005). PHYSAT was applied for the first time by Colomb et al. (2009) to a survey of atmospheric DMS concentrations carried out across the frontal systems that separate warm waters of the Indian Ocean south subtropical gyre from cool waters of the Indian sector of the Southern Ocean. The highest atmospheric levels of DMS were restricted to a zone rich in Chl where the dominant phytoplankton was DIAT. Based on phytoplankton culture work, one would have expected to find high DMS:Chl associated with a dominance of NANO, PHAEO or COC, and low ratios when SYN, PRO or DIAT dominate. However, there are limitations to this approach. The well known physiological adaptation of the Chl content of phytoplankton cells to environmental growth conditions could be responsible for part of the changes in DMS:Chl. DMS production could derive from the sub-fraction of marine organisms classified as non-dominant by PHYSAT. Also, by comparing DMS:Chl with the PHYSAT products we implicitly underestimate the role that the physical (ventilation, vertical mixing and the mixed layer depth, Simó and Pedrós-Alió, 1999), chemical (e.g. photooxidation, Bouillon and Miller, 2004) and biological removal processes (e.g. bacterial consumption, Kiene et al., 2000) play on DMS. This can not be assessed directly from satellite measurements at this time. Therefore, many important biotic and abiotic DMS loss terms can not be considered in our study. Nevertheless, PHYSAT is an important tool which enables us to evaluate the importance of phytoplankton group dominance in marine DMS dynamics at a large scale.

In this study, we use the Pacific Marine Environmental Laboratory (PMEL) global DMS database (http://saga. pmel.noaa.gov/dms/ after Kettle et al., 1999), some published and unpublished DMS transect data not yet available in the PMEL database, and $\mathrm{Chl}$ and PHYSAT data from the SeaWiFS sensor over the 1997-2007 period. We compare DMS:Chl to Phytoplankton Group Dominance (PGD) derived from PHYSAT, both spatially and temporally, to assess the role of phytoplankton dominance in controlling the regional and large scale variations of surface ocean DMS:Chl.

\section{Methods}

\subsection{DMS datasets}

DMS datasets used in this work were selected based on 3 criteria: (1) the overlap in time with the satellite data (19972007), (2) the high sampling resolution along cruise track and (3) the large extent of the datasets to cover contrasting areas of the Atlantic, Pacific and Indian basins (Fig. 1 and Table 1). They are numbered according to the contribution numbers (CN-139, CN-148, CN-169, CN-198 and CN-233) attributed by the global surface seawater DMS database manager to each dataset. DMS data are in units of $\mathrm{nM}$. The data are from sampling depths of $0-10 \mathrm{~m}$. There is no quality control in the database, all data sets are accepted regardless of measurement methods. No selection or elimination of historical data was performed in this study.

Additional DMS measurements in the Indian and Pacific sectors of the Southern Ocean were also used (Tortell and Long, 2009; Belviso, unpublished data). Six of the eight cruises were carried out in late spring and during the summer period, including all Southern Ocean cruises (Table 1).

The analytical methods used by the Pacific Marine Environmental Laboratory group and applied to $\mathrm{CN}-139$ and $\mathrm{CN}-$ 148 datasets are described in Bates et al. (1987). Extensive tests comparing DMS measurements from Niskin bottles, a bucket, and ship's pumping systems showed no significant differences in the DMS data collected from these different samplers.

Methods used by the University of California Irvine (CN-169 and CN-233 datasets) and University of British Columbia research groups can be found in Marandino et al. (2007) and Tortell and Long (2009), respectively.

During cruise UM0506 carried out in January 2006 by Tokyo University of Marine Science and Technology aboard the RT/V Umitaka-Maru, DMS concentrations were 


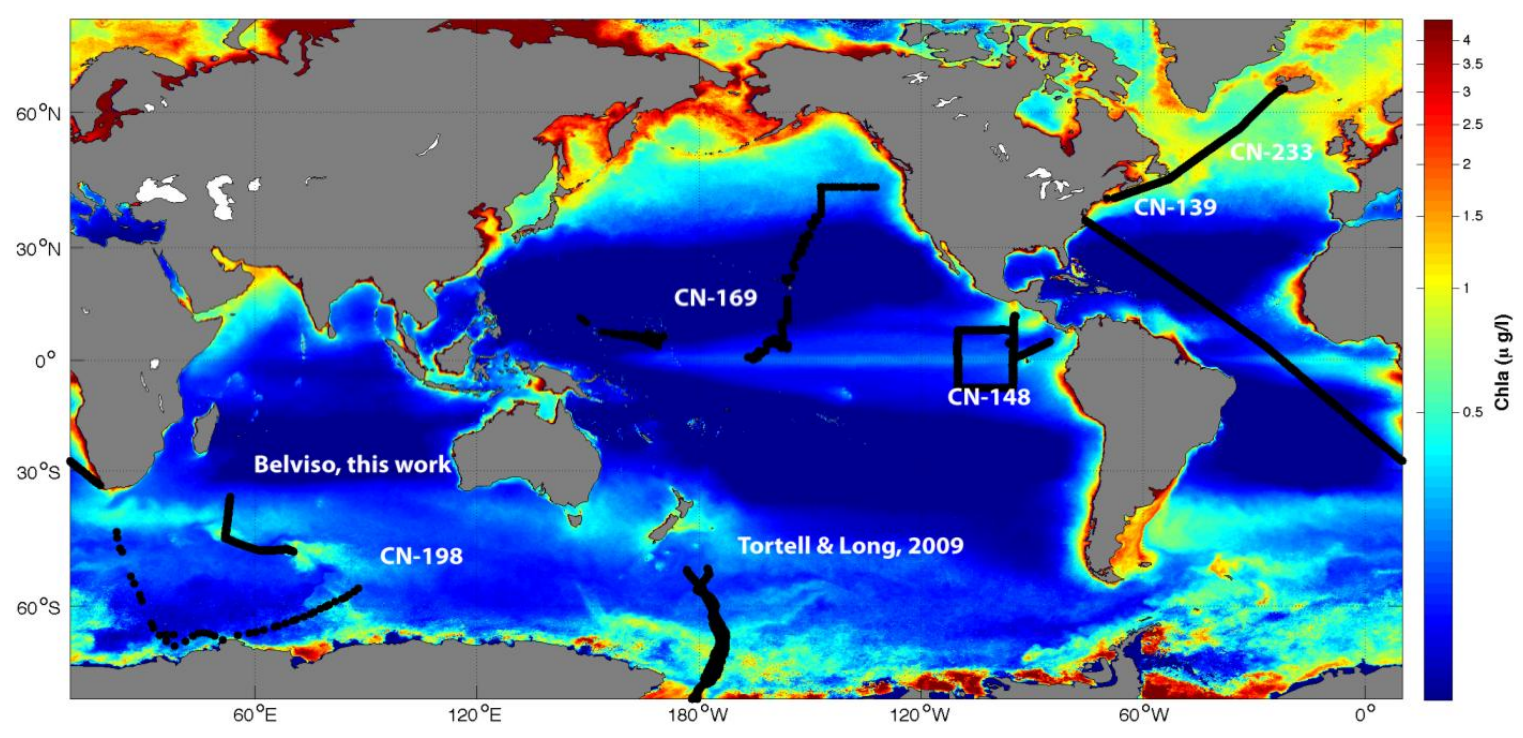

Fig. 1. DMS transects used in this study in conjunction with ocean color and PGD data. Details regarding the data sets can be found in Table 1. The color background is Chl climatology (2002-2007) from the MODIS AQUA sensor.

Table 1. Sea surface DMS datasets used in this study.

\begin{tabular}{lllll}
\hline Oceanic regions & DATE: year/start-end & $\begin{array}{l}\text { Number } \\
\text { of samples }\end{array}$ & $\begin{array}{l}\text { Contribution no. } \\
\text { and/or references }\end{array}$ \\
\hline \multirow{2}{*}{$\begin{array}{l}\text { Pacific } \\
\text { Ocean }\end{array}$} & Eastern & 2003/27 October-20 November & 1057 & CN-148 \\
& Western & $\begin{array}{l}\text { 2004/8 June-1 July } \\
\text { 2004/23 May-29 May }\end{array}$ & 70 & CN-169 Marandino et al. (2007) \\
\hline Atlantic & North-South & 1999/15 January-8 February & 666 & CN-139 Bates et al. (2001) \\
Ocean & North & 2007/17 July-24 July & 215 & CN-233 Marandino et al. (2008) \\
\hline \multirow{2}{*}{$\begin{array}{l}\text { Southern } \\
\text { Ocean }\end{array}$} & Indian sector & 2005/14 February-19 February & 178 & This work \\
& Indian sector & 2006/6 January-23 January & 55 & CN-198 \\
\hline
\end{tabular}

CN: Contribution number to the PMEL global DMS database (http://saga.pmel.noaa.gov/dms/).

measured as described by Kasamatsu et al. (2004). Water samples were collected with a rosette sampler equipped with 20-L Niskin bottles and a conductivity, temperature, depth (CTD) probe (Falmouth Scientific, Inc.). Surface seawater was also collected through the ship's pumping system from a depth of approximately $5 \mathrm{~m}$. No significant difference in the DMS data collected from these different samplers was found.

In the Indian sector of the Southern Ocean, DMS data were obtained during a transit from Kerguelen Island to La Réunion (Fig. 1) after the KEOPS cruise (Belviso et al., 2008). Water samples were collected underway by means of the Marion Dufresne II's clean seawater supply line used currently for $\mathrm{CO}_{2}$ fugacity measurements at approximately $5 \mathrm{~m}$ depth. A comparison was conducted between the clean seawater system (pump samples) and the CTD rosette sampler (bottle samples) during the KEOPS cruise. The analyti- cal protocol is described in Belviso et al. (2008). Figure S2 shows the effects of the clean seawater pumping system on the concentrations of total DMSP (DMSPt) and DMS, respectively. No gain or loss of DMSPt in the seawater circuit is observed because DMSPt data points fall close to the 1:1 line (Fig. S2a). On the contrary, DMS concentrations are generally higher in the clean water circuit than in CTD bottles (Fig. S2b). It is highly unlikely that the gain in DMS results from a filtration artifact because both the bottle samples and pump samples were treated similarly. DMS concentrations from the bottle and pump samples are linearly correlated. The slope of the relationship (DMS bottle $_{\text {DMS }}$ pump $)$ is $0.59(P<0.0001,95 \%$ confidence interval of the slope is $0.51-0.67)$ and the intercept $(0.18 \mathrm{nM})$ is not significant at the level of $5 \%(P=0.067,95 \%$ confidence interval of the intercept is $0-0.38 \mathrm{nM})$. There is no physical reason for 
the existence of a positive intercept because it would suggest that DMS is lost in the pump circuit at very low seawater DMS levels. On the contrary, the relationship shows a general gain of DMS in the pump circuit. In consequence, there are no physical or statistical reasons to reject the equation $[\mathrm{DMS}]_{\text {bottle }}=0.65 \times[\mathrm{DMS}]_{\text {pump }}\left(r^{2}=0.89, n=29, P<\right.$ $0.0001)$ which results from the forcing of the regression line through zero (Fig. S1b). Hence, a correction factor of 0.65 was applied to this specific set of underway measurements of DMS.

The overall precision of the DMS measurements is approximately $\pm 10 \%$. The instrument deployed at sea by Tortell and Long (2009) displays a higher detection limit (ca. $1 \mathrm{nM}$ ) than the other instruments (ca. $0.1 \mathrm{nM}$ ). Upper mixed layer DMS measurements are depth compatible with the ocean color measurements made by satellites.

\subsection{Satellite observations of ocean color and PGD}

\subsubsection{Ocean color}

Ocean color composites used in this study were computed from SeaWiFS daily L3-binned GAC data between 1997 and 2007 (9 km horizontal resolution, processing version $5.2 \mathrm{n}$ - http://oceancolor.gsfc.nasa.gov/). Chl from SeaWiFS has an uncertainty of ca. 30\%. No attempt was made here to compare SeaWiFS Chl data with ship chlorophyll measurements because (1) ship-based measurements were not available along each cruise track and (2), when available, there was no unification of the $\mathrm{Chl}$ measurement protocol and the Chl fluorescence sensors were not always calibrated. Moreover, diurnal fluorescence values exhibit light-dependent depressions resulting from non-photochemical quenching processes, so fluorescence-based $\mathrm{Chl}$ estimates are restricted to nighttime data. This was especially true in the eastern equatorial Pacific during cruise CN-148 (Behrenfeld and Boss, 2006).

\subsubsection{PGD}

The PHYSAT method (Alvain et al., 2005) was used to obtain composites of PGD along transects presented in Fig. 1. It is based on classical ocean color measurements in the visible spectrum and allows the classification of specific spectral anomalies (for $\mathrm{Chl}<4 \mathrm{mg} \mathrm{m}^{-3}$ and clear sky conditions) defined as:

$\operatorname{nLw}^{*}(\lambda)=\operatorname{nLw}(\lambda) / \operatorname{nLw}_{\text {ref }}(\lambda$, Chl $)$

where $\operatorname{nLw}(\lambda)$ is the spectral water-leaving radiance and $\mathrm{nLw}_{\mathrm{ref}}(\lambda, \mathrm{Chl})$ is a simple model of $\mathrm{nLw}(\lambda)$ that accounts only for the Chl concentration. Using this relationship, the first order signal variation (a function of $\mathrm{Chl}$ ) is removed and the second order variation from the total $\mathrm{nLw}(\lambda)$ spectra variability is isolated and defined by $\mathrm{nLw}^{*}(\lambda)$. Specific shapes and amplitudes of $\mathrm{nLw}^{*}(\lambda)$ have been associated with specific dominant phytoplankton groups using in situ measurements of biomarkers pigments determined by HPLC.

The PHYSAT algorithm was applied to the SeaWiFS daily L3-binned GAC data archive from 1997 to 2007 to identify the following dominant phytoplankton groups in surface waters (Alvain et al., 2005, 2008): Prochloroccocus (PRO), Synechococcus (SYN), nanoeucaryotes (NANO), Phaeocystis-like (PHAEO), coccolithophores (COC), and diatoms (DIAT). Daily records of phytoplankton groups at a resolution of $1 / 12^{\circ}$ were used to generate monthly composites of dominant phytoplankton group at $1 / 4^{\circ}$ by selecting the most frequently detected group for at least half of the valid (including unidentified) pixels. Note that when unidentified pixels prevail or when no phytoplankton group dominates, no PGD is assigned to a grid box.

Direct validation of PHYSAT dominant phytoplankton groups with ship-based observations is difficult because of the need for both bloom conditions and very clear skies. The only practical comparisons are with monthly composite satellite data. In their Fig. 6, Alvain et al. (2008) showed that $83 \%$ of the HPLC pigments inventories corresponding to NANO were associated with the same phytoplankton group in the PHYSAT monthly product. PHYSAT led to only a limited number of wrong identifications, mostly PRO in the Northern Hemisphere and SYN from one campaign in the Equatorial Pacific. Based on the results of Alvain et al. (2008), the probability of false detection for NANO is $17 \%$. The probability of false detection for PRO is considerably higher (ca. 50\%). However, most erroneous identifications for PRO (low DMSP producer) are associated with SYN (35\%) which is also a group belonging to the low DMSP producers. The probability of false detection of PRO is only $14 \%$ in the case that NANO is the dominant group detected by PHYSAT. The probability of substitution of SYN with NANO is $23 \%$. The third group of low DMSP producers is DIAT and, it that case, the probability of substitution of DIAT with NANO can be up to $40 \%$. Finally, the overall probability of concluding NANO dominance when the phytoplankton population is dominated by SYN, PRO or DIAT, is ca. $20 \%$. Since HPLC pigment samples were not collected during the different surveys listed in Table 1, it is impossible to repeat this validation exercise here. Among the most difficult groups to identify in this study are PHAEO and $\mathrm{COC}$, which are both important for DMS cycling in the surface ocean. PHAEO is known to have peculiar optical properties related to the white mucus exuded by cells during blooms. PHAEO is the more uncertain group. It has not been directly validated from coincident in situ measurements, but has been detected in areas where blooms of this organism have been reported and during periods of favorable growth (Alvain et al., 2008; Goffart et al., 2000; Smith et al., 2003). Hence, validation of PHAEO is a working progress. COC was the first phytoplankton group detected from space (Brown and Yoder, 1994). However, the SeaWiFS data used 
by the PHYSAT method, are screened to remove the suspended calcite signal using a threshold on $\mathrm{nLw}(\lambda)$, so that the PHYSAT results likely underestimate the actual size of coccolithophore blooms (Alvain et al., 2008).

To obtain sufficient data for this study, we have used the best satellite products available at the time of the study and applied no temporal and spatial regridding procedure. SeaWiFS data have been matched with DMS measurements according to date (month) and geographical coordinates.

\section{Results}

Both the climatological and cruise specific data are presented below. Monthly sea surface Chl concentrations and climatological (1998-2006) monthly PGD data are used to illustrate the regional context of the field studies (Sect. 3.1) in three broad areas: Equatorial Pacific and eastern North Pacific Ocean, North and South Atlantic Ocean, and the Indian and Pacific sectors of the Southern Ocean. Chl and PGD data extracted from the satellite records along the track of each survey, according to the date (month-year) of the DMS measurements, are used for subsequent comparison with DMS field observations (Sect. 3.2).

\subsection{Overview of main patterns of chlorophyll and PGD at the regional scale}

\subsubsection{Equatorial Pacific and eastern North Pacific Ocean}

The first track cut across the western warm pool (WWP) of the Equatorial Pacific during the spring season. Ultraoligotrophic $\left(\mathrm{Chl}<0.1 \mathrm{mg} \mathrm{m}^{-3}\right)$ and oligotrophic waters $\left(\mathrm{Chl} \sim 0.1 \mathrm{mg} \mathrm{m}^{-3}\right.$ ) occupied the center of the zone (Fig. 2a). Mesotrophic and eutrophic waters $\left(0.15<\mathrm{Chl}<1 \mathrm{mg} \mathrm{m}^{-3}\right)$ were found north of $30^{\circ} \mathrm{N}$, around Papua New Guinea and at the equator at $175^{\circ} \mathrm{E}$ (Fig. 2a). Climatological PGD in this region also showed latitudinal variations (Fig. 2b). The PHYSAT monthly climatology is investigated here because the monthly maps coinciding with the cruise tracks would have shown too many empty pixels because of cloud coverage and high aerosol loading of the atmosphere. NANO dominated north of $30^{\circ} \mathrm{N}$ and around Papua New Guinea. The center of the zone was occupied by SYN where most of the DMS measurements were made. In between the two zones, there was a $5^{\circ}$-wide zone where PRO dominated (around $25^{\circ} \mathrm{N}$, Fig. $2 \mathrm{~b}$ ) and a much wider zone south of $5^{\circ} \mathrm{N}$ where PRO and SYN alternated over short distances. The cruise ended in a mixed PRO-SYN zone.

In the central North Pacific during early summer 2004, oligotrophic waters were found between $10^{\circ} \mathrm{N}$ and $35^{\circ} \mathrm{N}$ (North Pacific Gyre (NPG), Fig. 2c). The transition from oligotrophy to mesotrophy was not the same northward (towards subtropical waters and the North American coasts) or southward (towards the equatorial divergence zone) in terms of PGD (Fig. 2d). Northward, there was a band dominated by PRO and NANO. Some areas with concentrated levels of DIAT were also observed there. Southward, there were no marked changes in PHYSAT PGD. Oligotrophic waters of the NPG and the more productive waters near the equator displayed the same mixture of SYN and PRO dominances. SYN dominance prevailed in the zone west of $170^{\circ} \mathrm{W}$ between $10^{\circ} \mathrm{N}$ and $25^{\circ} \mathrm{N}$.

In November 2003, mesotrophic waters were found off the Central and South American coasts and along the equator (Fig. 2e). The main features in PGD in this region were: (1) NANO dominated off Central America, (2) DIAT dominated off Peru, and (3) PRO dominated along the equator (Fig. 2f). SYN dominance prevailed south of $4^{\circ} \mathrm{S}$ and west of $100^{\circ} \mathrm{W}$. The DMS survey was carried out mostly in the mixed SYN-PRO zone.

\subsubsection{North and South Atlantic Ocean}

The January $1999 \mathrm{Chl}$ map (Fig. 3a) shows three zones of high productivity (Guinea dome, Benguela upwelling and the equatorial divergence) and two zones of low productivity (north and south subtropical gyres). The ship did not cut across the ultra-oligotrophic waters of the South Atlantic gyre $\left(\mathrm{Chl}<0.1 \mathrm{mg} \mathrm{m}^{-3}\right)$. In January, the oligotrophic waters of the North Atlantic gyre $\left(20^{\circ} \mathrm{N}\right)$ exhibited PRO dominance (Fig. 3b) while the northern edge of the South Atlantic gyre exhibited PRO and NANO dominances. Elsewhere, NANO dominance prevailed especially in the productive tropical and equatorial waters. In summer, the western North Atlantic is a biologically productive region with $\mathrm{Chl}$ concentrations north of $44^{\circ} \mathrm{N}$ rising up to $2 \mathrm{mg} \mathrm{m}^{-3}$ (Fig. 3c). The PHYSAT climatology of the area shows a general prevalence of NANO west of $40^{\circ} \mathrm{W}$ and in the Labrador Sea (Fig. 3d). Diatoms were confined to the northeast quarter of the investigated area. Hence, according to the PHYSAT climatology, there were NANO blooms west of $40^{\circ} \mathrm{W}$ and DIAT blooms east of $40^{\circ} \mathrm{W}$. Coccolithophores are dominant only over the Icelandic shelf. The DMS survey covered the NANO and mixed DIAT-NANO zones.

\subsubsection{Indian and Pacific sectors of the Southern Ocean}

The PHYSAT images show that PGD is considerably patchier in the Indian and Pacific sectors of the Southern Ocean than in the areas investigated previously (Fig. 4, right panels). Nevertheless, some general features can be seen in the late spring and early summer months. In the Indian sector of the Southern Ocean, between $38^{\circ} \mathrm{S}$ and $46^{\circ} \mathrm{S}$, SYN dominance is found in a band rich in $\mathrm{Chl}$ (Fig. 4a) which coincides with the strong frontal systems separating subtropical waters (NANO and PRO dominances) from subantarctic and antarctic waters (NANO, PHAEO and DIAT dominances, Fig. 4b). NANO dominance is associated with the Chl patches located off Kerguelen Island (Fig. 4a and c). Diatoms dominate more 


\section{CHLOROPHYLL}

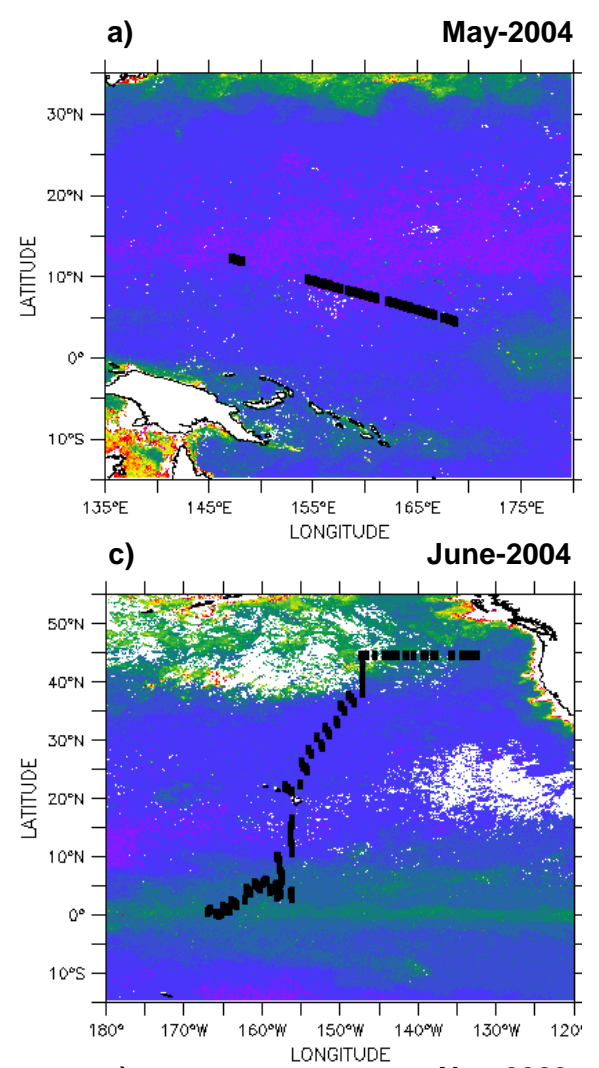

e)

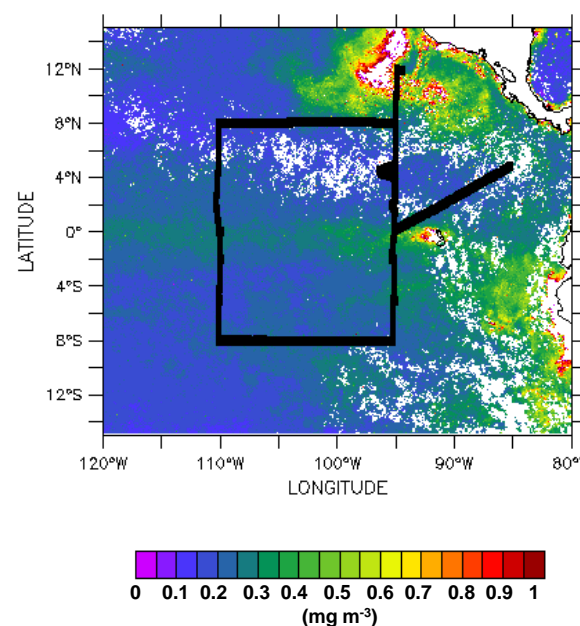

\section{PFT-CLIMATOLOGY}

b)

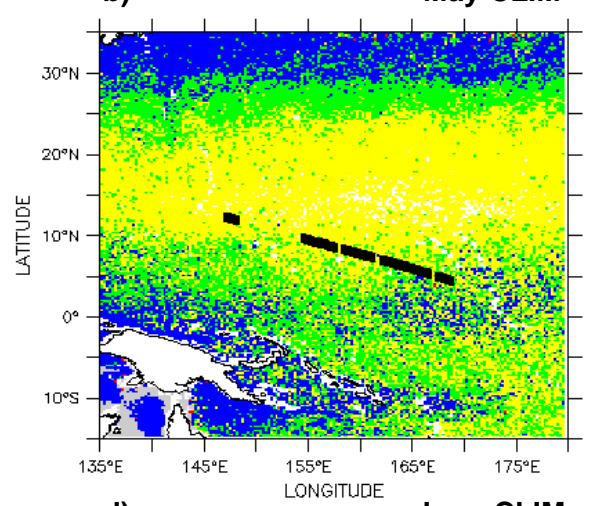

d)

June-CLIM

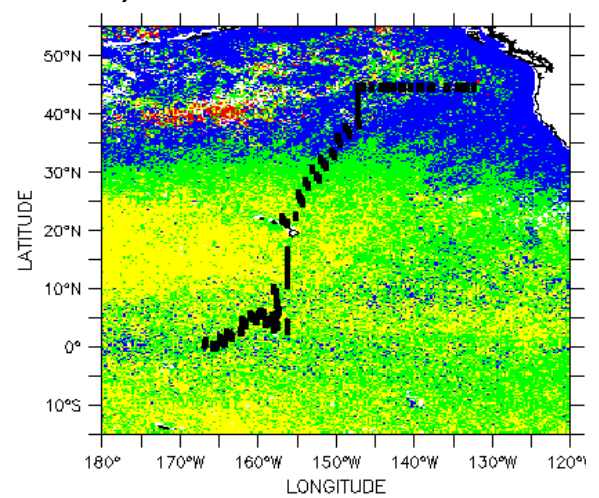

f)
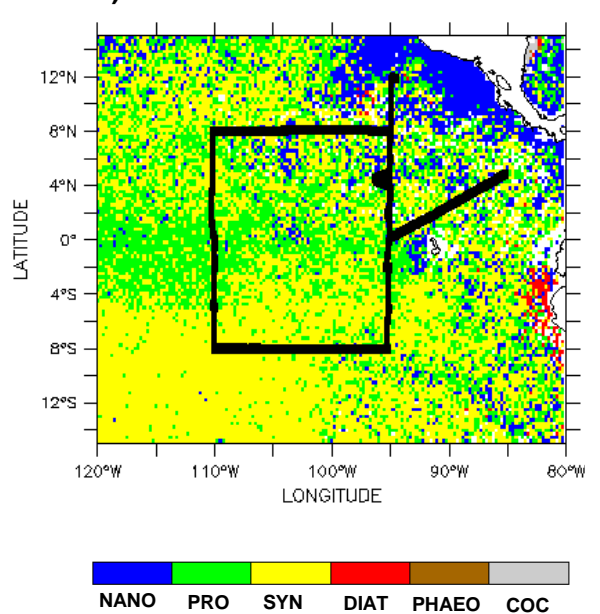

Fig. 2. Regional monthly composites of Chl concentration (left panels, units $\mathrm{mg} \mathrm{m}^{-3}$ ) and monthly climatological composites (1998-2006) of the dominant phytoplankton groups detected by PHYSAT (right panels). (a, b) western Equatorial Pacific, (c, d) central Equatorial Pacific and eastern North Pacific, (e, f) eastern Equatorial Pacific. Dominant phytoplankton groups are: nanoeucaryotes (NANO), Prochloroccocus (PRO), Synechococcus (SYN), diatoms (DIAT), Phaeocystis-like (PHAEO) and coccolithophores (COC).

to the south (Fig. 4d). However, between $20^{\circ} \mathrm{E}$ and $70^{\circ} \mathrm{E}$ and south of $64^{\circ} \mathrm{S}$, DIAT dominance is replaced by NANO dominance (Fig. 4d). PHYSAT dominances alternate between PRO, SYN, NANO and DIAT over short distances in the
Pacific sector of the Southern Ocean in December north of $56^{\circ} \mathrm{S}$ and south of $62^{\circ} \mathrm{S}$, whereas DIAT dominance clearly takes over between $56^{\circ} \mathrm{S}$ and $62^{\circ} \mathrm{S}$ (Fig. 4f). 


\section{CHLOROPHYLL}

a)

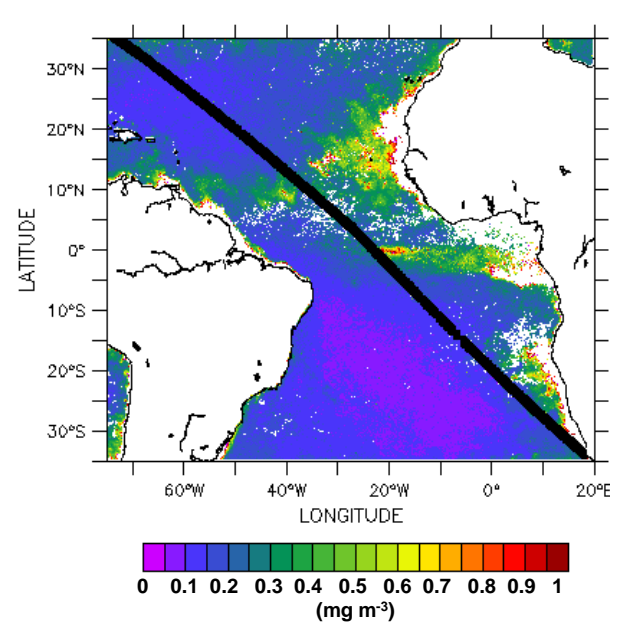

c)

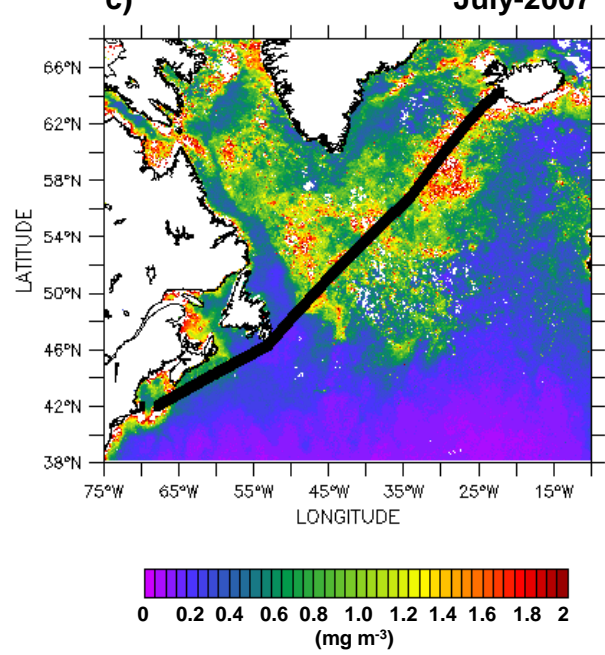

\section{PFT-CLIMATOLOGY}

b)
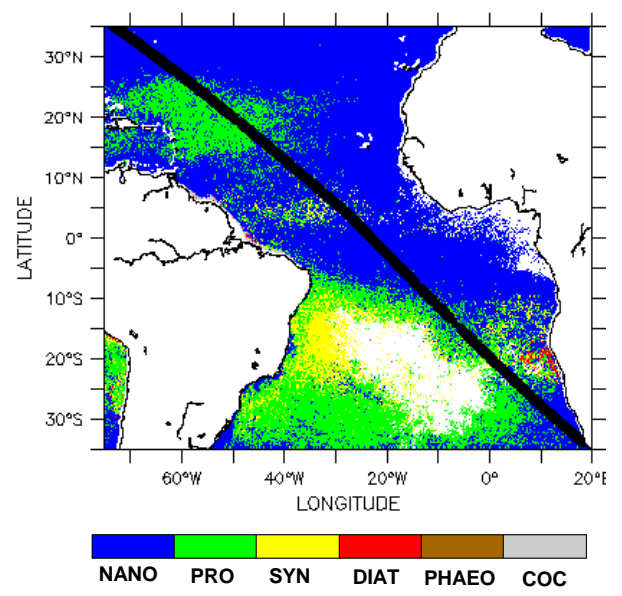

d) July-CLIM

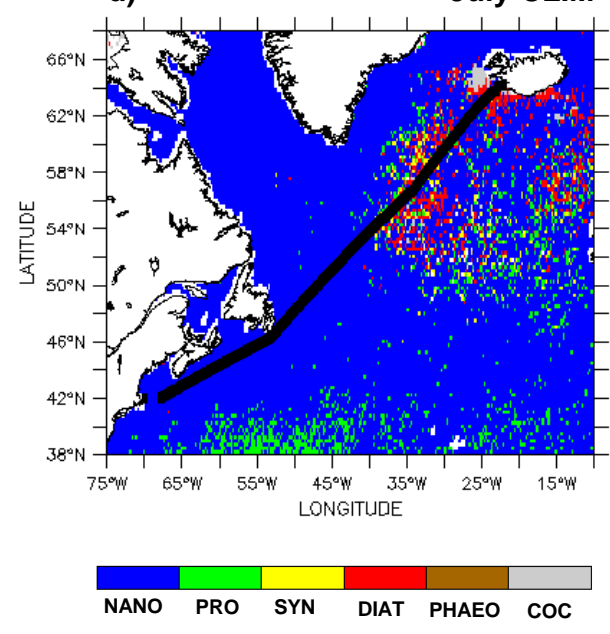

Fig. 3. Same as Fig. 2 but for the Atlantic Ocean. (a, b) North and South Atlantic, (c, d) western North Atlantic.

\subsection{DMS:Chl and PHYSAT monthly PGD data extracted along cruise tracks}

The spatial and temporal variations of the following parameters were investigated: sea surface temperature (SST), sea surface salinity (SSS) (when necessary to better characterize the water masses), Chl concentration from SeaWiFS, PGD from PHYSAT, DMS concentration and DMS concentration normalized to satellite $\mathrm{Chl}$ concentration (DMS:Chl). Here $\mathrm{Chl}$ is used has a field metric for phytoplankton biomass, although Chl variability can be strongly influenced by physiological shifts in intracellular pigmentation in response to changing growth conditions (light, nutrients, temperature). In the eastern equatorial Pacific Ocean (CN-148, Fig. 1), Behrenfeld and Boss (2006) demonstrated that the mixed layer growth conditions of phytoplankton were sufficiently stable that acclimation to light and nutrient stress did not have a significant influence on the relationship between chlorophyll concentration and phytoplankton carbon biomass. The homogeneity of the eastern equatorial Pacific and the Southern Ocean with respect to phytoplankton physiology (Behrenfeld and Boss, 2006) makes these areas more suitable to investigating the effect of phytoplankton dominance on DMS:Chl. Under such conditions, physiological shifts in intracellular chlorophyll concentration are better constrained than in highly variable environments such as along transect $\mathrm{CN}-139$ in the Atlantic Ocean, and along $\mathrm{CN}$ 233 also. 


\section{CHLOROPHYLL}

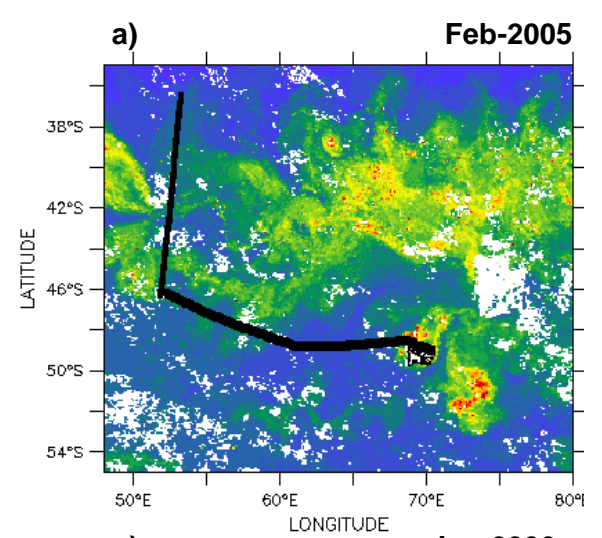

c)

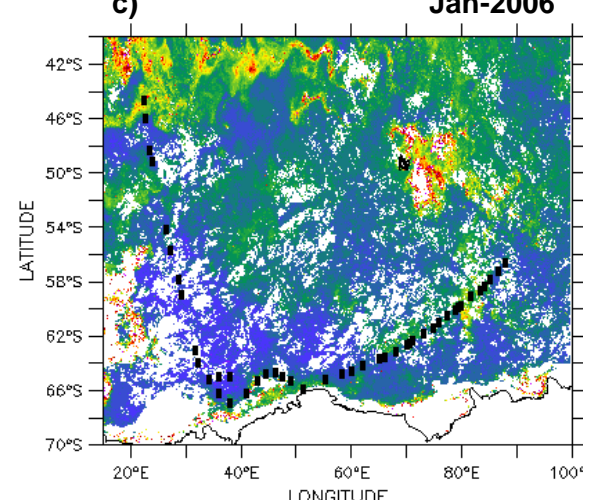

e)

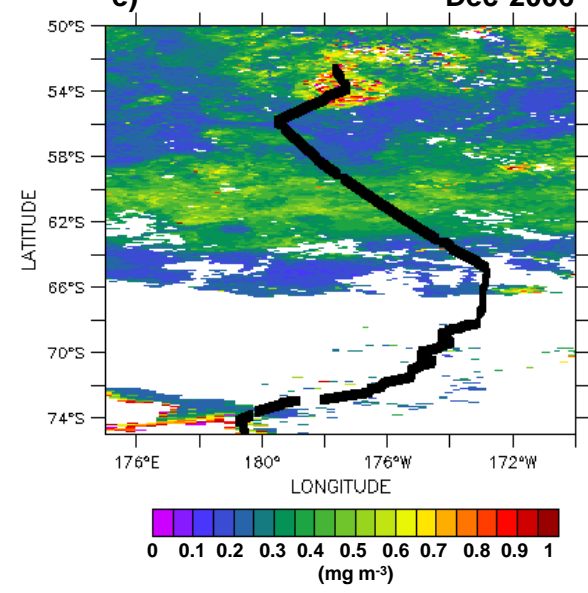

\section{PFT-CLIMATOLOGY}

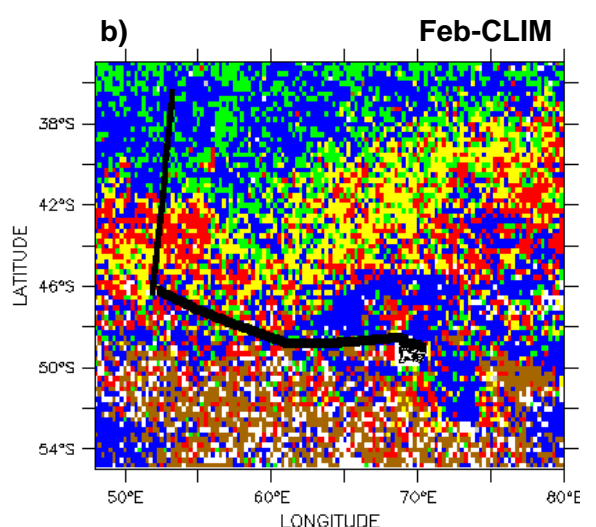

d)
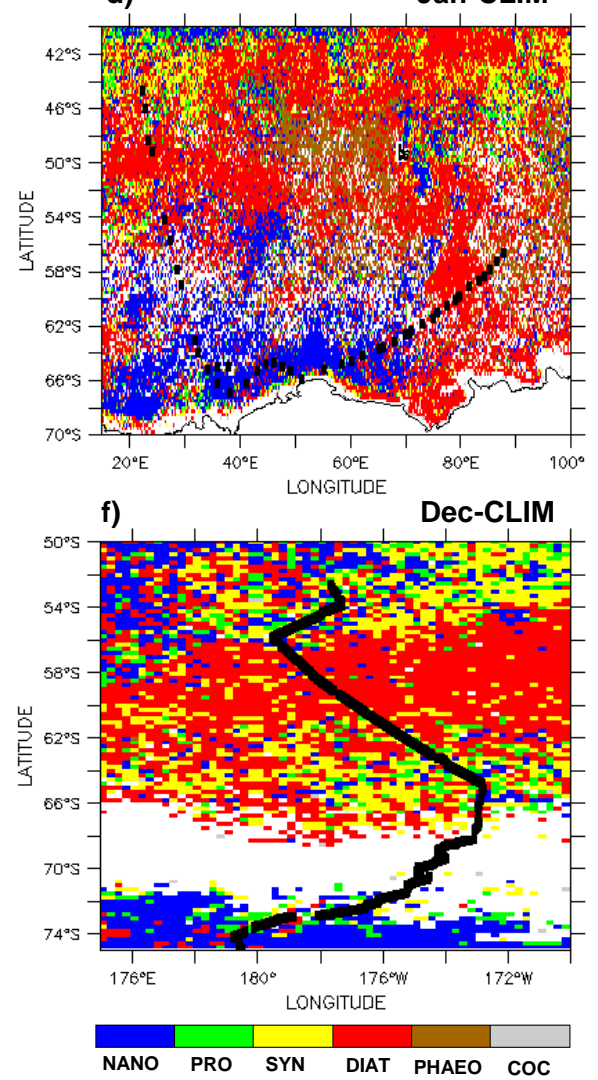

Fig. 4. Same as Fig. 2 but for the Indian and Pacific sectors of the Southern Ocean. (a, b, c, d) Indian sector of the Southern Ocean, (e, f) Pacific sector of the Southern Ocean.

\subsubsection{Indian and Pacific sectors of the Southern Ocean}

Indian sector of the Southern Ocean

Approximately 200 seawater samples were analyzed for DMS along the cruise track of RV Marion Dufresne II in late February 2005 between the islands of Kerguelen and Crozet, and across the frontal system north of Crozet Island on the way to La Réunion (Fig. 5a and b). The ship followed the same route as in December 1997, along which DMS measurements were performed for the first time by Sciare et al. (1999). DMS concentrations range between 0.25 and $6.1 \mathrm{nM}$ (Fig. 5c and d). The range of the DMS concentrations measured in 2005 was large (factor of 25) but not as large as observed in 1997 (Sciare et al., 1999; factor of 40). The lowest DMS concentrations were located in shallow waters 

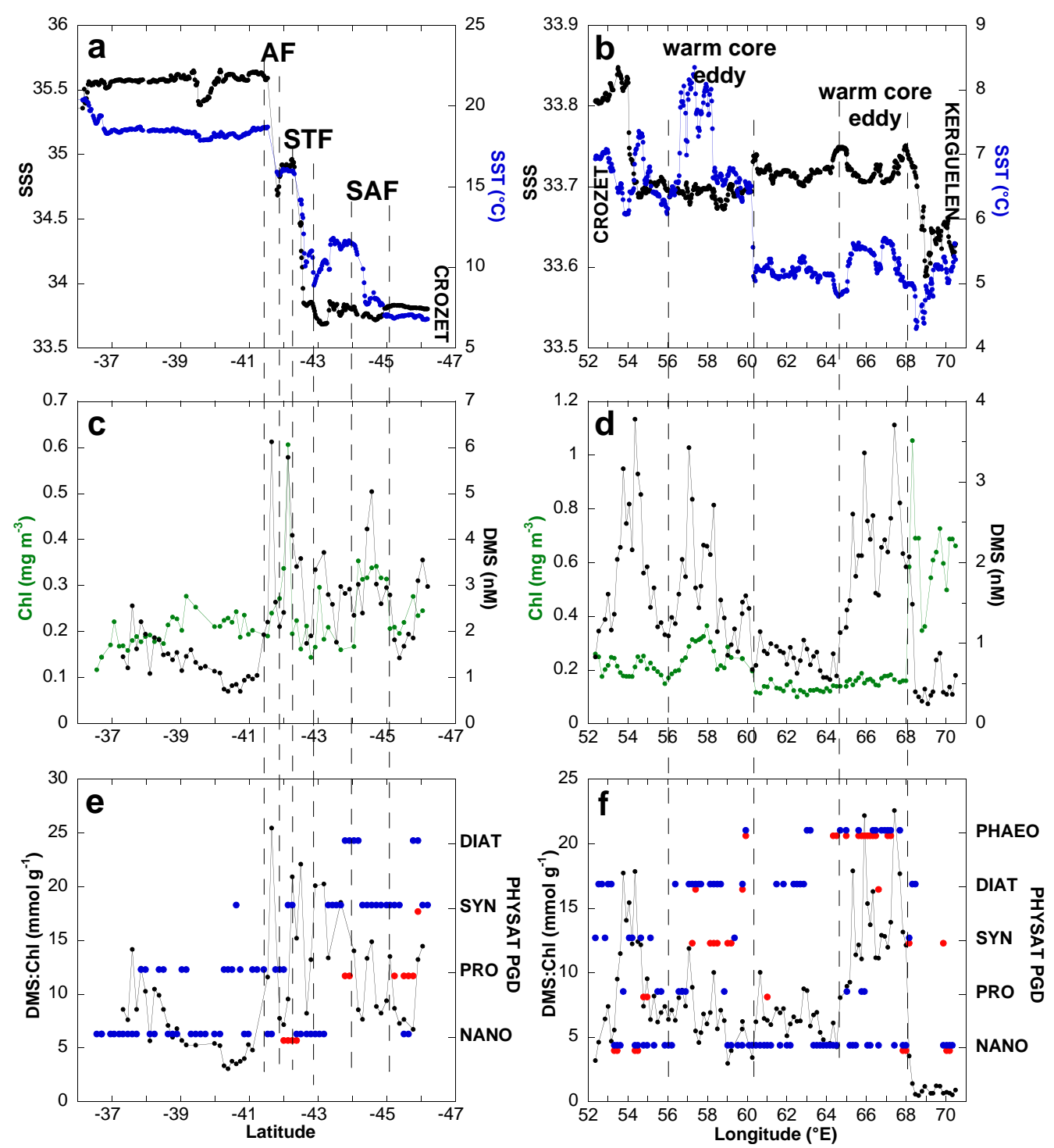

Fig. 5. Spatial variations of (a, b) sea surface temperature (SST: ${ }^{\circ} \mathrm{C}$, in blue) and salinity (SSS, in black), (c, d) ocean color $\left(\mathrm{Chl}: \mathrm{mg} \mathrm{m}{ }^{-3}\right.$, in green) and sea surface dimethylsulfide concentration (DMS: nM, in black), (e, f) DMS-to-Chl ratio (DMS:Chl, mmol g ${ }^{-1}$, in black) and monthly (red dots) and monthly climatological (blue dots) composites of phytoplankton group dominance along two DMS transects carried out in February 2005 in the Indian Sector of the Southern Ocean (right panels: longitudinal transect between Kerguelen and Crozet, left panels: latitudinal transect between Crozet and La Réunion). AF: Agulhas front, STF: subtropical front, SAF: subantarctic front.

$(<200 \mathrm{~m})$ over the Kerguelen Plateau, north of the polar front during a phytoplankton bloom (Fig. 5d, see also Park et al., 2008). DMS:Chl are as low as $0.5 \mathrm{mmol} \mathrm{g}^{-1}$ there (Fig. 5f). Unfortunately, few PHYSAT data were available in this area to evaluate the PGD in the bloom area (Fig. 5f). However, climatological data suggest NANO or SYN dominance but not DIAT or PHAEO. In the warm core eddy over the slope $\left(200 \mathrm{~m}-2000 \mathrm{~m}\right.$ depth) between $65^{\circ} \mathrm{E}$ and $68^{\circ} \mathrm{E}$ (Fig. 5b), Chl levels were 2-6-fold lower than over the plateau. The DMS trend is the exact opposite (Fig. 5d). DMS:Chl peaks over the slope with values up to $22 \mathrm{mmol} \mathrm{g}^{-1}$, increasing by a factor of 40 over one degree longitude. The dominant phytoplankton group was PHAEO both climatologically and during February 2005 data (Fig. 5f). The ship cut across a second warm core eddy between $56^{\circ} \mathrm{E}$ and $60^{\circ} \mathrm{E}$ (Fig. 5b). Satellite altimetry suggests that this anticyclonic eddy detached from the Antarctic circumpolar current several weeks before (data not shown). It was as rich in DMS as the eddy located over the slope but its Chl content was roughly twice higher. Consequently DMS:Chl were not as high as they were further east and the associated PGD was mainly SYN. A third water mass was surveyed between $56^{\circ} \mathrm{E}$ and the coast of Crozet Island. It was as rich in DMS as the other water masses but displayed intermediate Chl levels (Fig. 5d). 

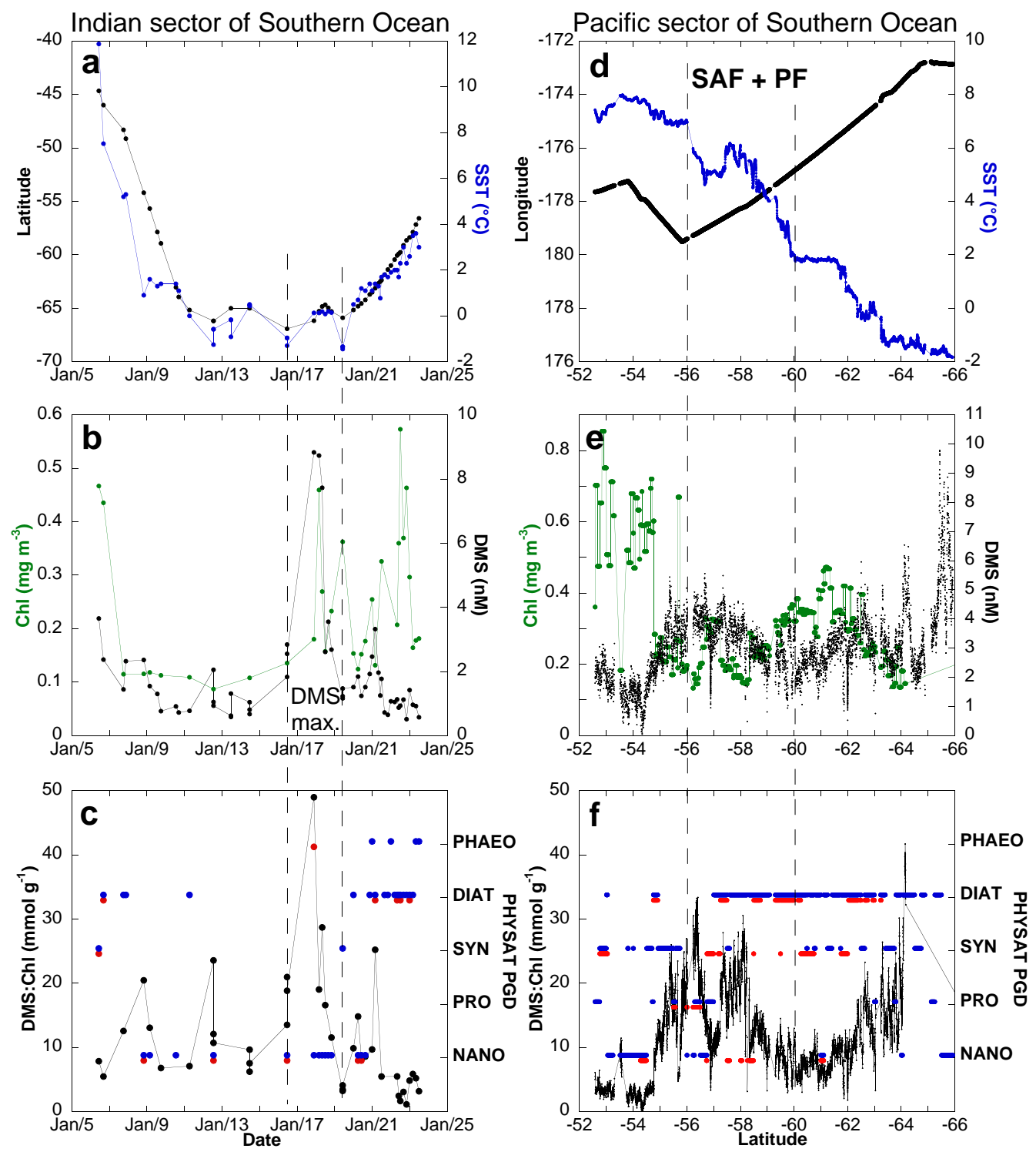

Fig. 6. Spatial and temporal distributions of the following parameters in the Indian (left panels) and Pacific (right panels) sectors of the Southern Ocean: (a, d) sea surface temperature (SST: ${ }^{\circ} \mathrm{C}$, in blue) and latitude/longitude (in black), (b, e) ocean color $\left(\mathrm{Chl}: \mathrm{mg} \mathrm{m}^{-3}\right.$, in green) and sea surface dimethylsulfide concentration (DMS: nM, in black), (c, f) DMS-to-Chl ratio (DMS:Chl, $\mathrm{mmol} \mathrm{g}^{-1}$, in black) and monthly (red dots) and monthly climatological (blue dots) composites of phytoplankton group dominance. SO: Southern Ocean, SAF: subantarctic front, PF: polar front.

The highest ratios (up to $18 \mathrm{mmol}^{-1}$ ) were measured in a salinity front (Fig. 5b) and were associated with NANO dominance (Fig. 5f).

Unfortunately the transects of DMS, Chl (Fig. 5c) and PHYSAT (Fig. 5e) across the three fronts located north of Crozet (Fig. 5a) are not at the same spatial resolution. Some coherence between the February 2005 data and the PHYSAT monthly climatology was found for NANO but not for PRO. NANO dominance was detected between the Agulhas front and the subtropical front in association with two peaks of DMS and Chl which coincided spatially (Fig. 5e). However, the DMS:Chl was not homogeneous but instead decreased by a factor of three over half a degree of latitude. The DMS:Chl also was highly variable in the transition zone between the Agulhas front and the warm subtropical water but PGD data were not available.

RT/V Umitaka Maru also explored the Indian Sector of the Southern Ocean during summer, mainly south of the polar front and along the pack-ice where SSTs were below zero (Fig. 6, left panels). Only one area with concentrated level of DMS (8-9 nM) was found during the transect at the limit of the pack-ice in mid-January (Fig. 6b). The DMS:Chl "hot 
Table 2. Mean DMS:Chl ratios sorted by oceanic regions and by phytoplankton group dominance.

\begin{tabular}{|c|c|c|c|c|c|c|}
\hline & \multirow{2}{*}{$\begin{array}{l}\text { Sampling location } \\
\text { Contribution number }(\mathrm{CN}) \\
\text { or references }\end{array}$} & \multicolumn{5}{|c|}{ Phytoplankton group dominance DMS:Chl ratio in $\mathrm{mmol} \mathrm{g}^{-1}\left(\right.$ mean $\pm 1 \mathrm{SD} ;$ median; $n$ ) Student $\mathrm{t}$-test $\mathrm{t}^{\mathrm{a}}$} \\
\hline & & NANO & PHAEO & PRO & SYN & DIAT \\
\hline \multirow{7}{*}{ 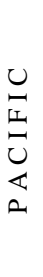 } & North Pacific $>20^{\circ} \mathrm{N}$ & $23.0 \pm 11.6 ; 17.0 ; 7$ & - & $\begin{array}{l}23.4 \pm 7.1 ; 24.0 ; 7 \\
\text { NS } P=0.933\end{array}$ & $\begin{array}{l}12.2 \pm 5.4 ; 11.9 ; 9 \\
\text { NS } P=0.052\end{array}$ & - \\
\hline & Equatorial Pacific & $13.7 \pm 2.7 ; 13.7 ; 25$ & - & $17.8 \pm 9.8 ; 15.7 ; 85$ & $14.6 \pm 5.0 ; 13.8 ; 404$ & - \\
\hline & $8^{\circ} \mathrm{S}-2^{\circ} \mathrm{S}, 0^{\circ}-16^{\circ} \mathrm{N}$ & & & $\mathrm{S}, P<0.0001$ & NS, $P=0.148$ & \\
\hline & $\mathrm{CN}-148, \mathrm{CN}-169$ & & & & & \\
\hline & Equatorial Pacific & $7.0 \pm 0.6 ; 7.1 ; 10$ & - & $6.2 \pm 0.6 ; 6.3 ; 44$ & $8.4 \pm 2.4 ; 8.1 ; 47$ & - \\
\hline & $2^{\circ} \mathrm{S}-0^{\circ}(\mathrm{ED})$ & & & $\mathrm{S}, P=0.003$ & $\mathrm{~S}, P=0.0007$ & \\
\hline & $\mathrm{CN}-148$ & & & & & \\
\hline \multirow{10}{*}{ 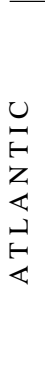 } & North Atlantic & $4.6 \pm 2.2 ; 3.9 ; 88$ & - & $3.2 \pm 1.0 ; 3.0 ; 15$ & $7.1 \pm 2.4 ; 6.8 ; 13$ & $4.8 \pm 1.5 ; 4.5 ; 23$ \\
\hline & $\mathrm{CN}-233$ & & & $\mathrm{~S}, P=0.0001$ & $\mathrm{~S}, P=0.0028$ & NS, $P=0.495$ \\
\hline & Equatorial Atlantic & $4.4 \pm 1.4 ; 4.4 ; 19$ & - & - & - & - \\
\hline & $2^{\circ} \mathrm{S}-0^{\circ}(\mathrm{ED})$ & & & & & \\
\hline & $\mathrm{CN}-139$ & & & & & \\
\hline & South Atlantic & $3.6 \pm 3.1 ; 2.8 ; 20$ & - & $-; 1.8 ; 2$ & - & - \\
\hline & Benguela Upwelling (BU) & & & & & \\
\hline & CN-139 & & & & & \\
\hline & North \& South Atlantic & $12.2 \pm 11.6 ; 10.1 ; 249$ & - & $16.9 \pm 8.7 ; 13.5 ; 141$ & $13.8 \pm 7.8 ; 12.2 ; 31$ & - \\
\hline & $\begin{array}{l}\text { except ED \& BU } \\
\text { CN-139 }\end{array}$ & & & $\mathrm{S}, P<0.0001$ & NS, $P=0.31$ & \\
\hline \multirow{6}{*}{ 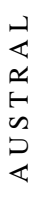 } & Indian Sector of & $12.7 \pm 6.3 ; 12.4 ; 21$ & $15.1 \pm 11.2 ; 12.2 ; 13$ & $7.7 \pm 1.2 ; 7.5 ; 6$ & $6.4 \pm 3.8 ; 6.3 ; 10$ & $8.2 \pm 7.4 ; 5.5 ; 8$ \\
\hline & Southern Ocean & & $\mathrm{NS}, P=0.505$ & $\mathrm{~S}, P=0.0016$ & $\mathrm{~S}, P=0.0022$ & NS, $P=0.147$ \\
\hline & $\mathrm{CN}-128$; this work & & & & & \\
\hline & Pacific Sector of & $9.1 \pm 6.9 ; 8.5 ; 302$ & - & $23.1 \pm 5.3 ; 23.2 ; 155$ & $7.6 \pm 2.9 ; 7.7 ; 851$ & $11.3 \pm 4.8 ; 10.3 ; 897$ \\
\hline & Southern Ocean (DEC) & & & $\mathrm{S}, P<0.0001$ & $\mathrm{~S}, P=0.0002$ & $\mathrm{~S}, P<0.0001$ \\
\hline & Tortell and Long (2009) & & & & & \\
\hline
\end{tabular}

${ }^{a}$ Student t-test for unpaired data with unequal variance (NANO vs. other phytoplankton groups).

$\mathrm{S}$ : significant, NS: non significant, $P$ : t-test probability, DEC: December

spot" $\left(50 \mathrm{mmol} \mathrm{g}^{-1}\right)$ coincided with the sole PHAEO dominance of the area (Fig. 6c). In late January, the ship cut across a diatom bloom which was associated with considerably lower ratios (i.e. about a 10 -fold decrease was observed between the PHAEO and DIAT areas). The mean DMS:Chl associated with DIAT was highly variable $8.2 \pm 7.4 \mathrm{mmol} \mathrm{g}^{-1}$ $(n=8)$.

When the DMS:Chl data sets collected in summer in the Indian sector of the Southern Ocean are pooled together with NANO dominance used as the reference, it is clear that mean DMS:Chl are significantly lower (i.e. about half lower) in SYN or PRO than in NANO dominated areas (Table 2). Mean DMS:Chl associated with $\mathrm{NANO}+\mathrm{PHAEO}$ and PRO + SYN + DIAT were $13.6 \pm 8.4 \mathrm{mmol} \mathrm{g}^{-1}(n=34)$ and $7.3 \pm 4.8 \mathrm{mmol} \mathrm{g}^{-1}(n=24$, Table 3$)$, respectively, a statistically significant difference $(P=0.0006)$.

\section{Pacific sector of the Southern Ocean}

In December 2006, Tortell and Long (2009) surveyed the latitudinal distribution of DMS in the Southern Ocean roughly along the dateline from the Ross Sea up to $53^{\circ} \mathrm{S}$ (Fig. 6, right panels). In the present study, the investigation area is restricted to surface waters free of ice $\left(53^{\circ} \mathrm{S}\right.$ and $\left.64^{\circ} \mathrm{S}\right)$. SST decreased steadily with increasing latitude except in the area of the subantarctic and polar fronts (SAF and PF, respectively) which were crossed between $56^{\circ} \mathrm{S}$ and $60^{\circ} \mathrm{S}$ (Fig. 6d). The largest phytoplankton population was observed north of $55^{\circ} \mathrm{S}$ (Fig. 6e). This high Chl was associated with the lowest values of the DMS:Chl (Fig. 6f). Unfortunately, PHYSAT data were very limited in this high $\mathrm{Chl}$ area. The limited data suggest that SYN dominated in the north and NANO in the south. DMS:Chl increased sharply south of the high $\mathrm{Chl}$ area and reached $35 \mathrm{mmolg}^{-1}$ in the center of the SAF where the dominant phytoplankton was PRO (Fig. 6f). A similar high-DMS and low-Chl zone was found between $57^{\circ} \mathrm{S}$ and $58^{\circ} \mathrm{S}$ but in this case the dominant phytoplankton group was NANO. Several patches are seen south of $58^{\circ} \mathrm{S}$ where PGD was DIAT or SYN but rarely NANO. Mean DMS:Chl associated with NANO, PRO, SYN or DIAT are shown in Table 2. When PRO, SYN and DIAT data are pooled together and compared with NANO, the difference was significant (Table $3, P=0.0005$ ) but the low DMSP producers displayed a slightly higher mean DMS:Chl than the high DMSP producers. 
Table 3. Mean DMS:Chl ratios sorted by oceanic regions and by phytoplankton group dominance to trace the dominance of high and low DMSP producers.

\begin{tabular}{|c|c|c|c|c|}
\hline & \multirow{2}{*}{$\begin{array}{l}\text { Sampling location } \\
\text { Contribution number }(\mathrm{CN}) \text { or } \\
\text { references }\end{array}$} & \multicolumn{2}{|c|}{ DMS:Chl ratio in $\mathrm{mmol} \mathrm{g}^{-1}($ mean $\pm 1 \mathrm{SD} ;$ median; $n)$} & \multirow[t]{2}{*}{ Student t-test $\mathrm{t}^{\mathrm{a}}$} \\
\hline & & $\begin{array}{l}\text { High DMSP producers } \\
\text { NANO + PHAEO }\end{array}$ & $\begin{array}{l}\text { Low DMSP producers } \\
\text { PRO + SYN + DIAT }\end{array}$ & \\
\hline \multirow{3}{*}{ 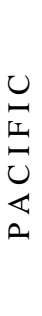 } & $\begin{array}{l}\text { North Pacific }>20^{\circ} \mathrm{N} \\
\mathrm{CN}-169\end{array}$ & $23.0 \pm 11.6 ; 17.0 ; 7$ & $17.1 \pm 8.3 ; 16.9 ; 16$ & NS, $P=0.257$ \\
\hline & $\begin{array}{l}\text { Equatorial Pacific } \\
8^{\circ} \mathrm{S}-2^{\circ} \mathrm{S}, 0^{\circ}-16^{\circ} \mathrm{N} \\
\mathrm{CN}-148, \mathrm{CN}-169\end{array}$ & $13.7 \pm 2.7 ; 13.7 ; 25$ & $15.2 \pm 6.3 ; 14.0 ; 489$ & $\mathrm{~S}, P=0.023$ \\
\hline & $\begin{array}{l}\text { Equatorial Pacific } \\
2^{\circ} \mathrm{S}-0^{\circ} \text { (ED) } \\
\mathrm{CN}-148\end{array}$ & $7.0 \pm 0.6 ; 7.1 ; 10$ & $7.4 \pm 2.1 ; 6.6 ; 91$ & NS, $P=0.201$ \\
\hline \multirow{4}{*}{ 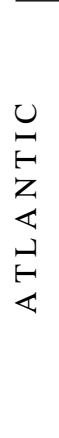 } & $\begin{array}{l}\text { North Atlantic } \\
\text { CN-233 }\end{array}$ & $4.6 \pm 2.2 ; 3.9 ; 88$ & $4.9 \pm 2.2 ; 4.4 ; 51$ & NS, $P=0.439$ \\
\hline & $\begin{array}{l}\text { Equatorial Atlantic } \\
2^{\circ} \mathrm{S}-0^{\circ} \text { (ED) } \\
\mathrm{CN}-139\end{array}$ & $4.4 \pm 1.4 ; 4.4 ; 19$ & - & - \\
\hline & $\begin{array}{l}\text { South Atlantic } \\
\text { Benguela Upwelling (BU) } \\
\text { CN-139 }\end{array}$ & $3.6 \pm 3.1 ; 2.8 ; 20$ & $-; 1.8 ; 2$ & $\mathrm{~S}, P=0.017$ \\
\hline & $\begin{array}{l}\text { North \& South Atlantic } \\
\text { except ED \& BU } \\
\text { CN-139 }\end{array}$ & $12.2 \pm 11.6 ; 10.1 ; 249$ & $16.4 \pm 8.6 ; 13.2 ; 172$ & $\mathrm{~S}, P<0.0001$ \\
\hline \multirow{2}{*}{ 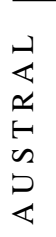 } & $\begin{array}{l}\text { Indian Sector of } \\
\text { Southern Ocean } \\
\text { CN-128; this work }\end{array}$ & $13.6 \pm 8.4 ; 12.3 ; 34$ & $7.3 \pm 4.8 ; 7.3 ; 24$ & $\mathrm{~S}, P=0.0006$ \\
\hline & $\begin{array}{l}\text { Pacific Sector of } \\
\text { Southern Ocean (DEC) } \\
\text { Tortell and Long (2009) }\end{array}$ & $9.1 \pm 6.9 ; 8.5 ; 302$ & $10.6 \pm 5.8 ; 9.3 ; 1903$ & $\mathrm{~S}, P=0.0005$ \\
\hline
\end{tabular}

a Student t-test for unpaired data with unequal variance, S: significant, NS: non significant, $P$ : t-test probability, DEC: December

\subsubsection{Equatorial Pacific and eastern North Pacific Ocean}

In the Pacific western warm pool (WWP), SST was over $29^{\circ} \mathrm{C}$ (Fig. 7a) and surface waters displayed low phytoplankton biomass $\left(\mathrm{Chl}<0.1 \mathrm{mg} \mathrm{m}^{-3}\right.$, Fig. 7 b). The DMS:Chl ranged between 13 and $55 \mathrm{mmol} \mathrm{g}^{-1}$ and was on average $25 \pm 7.5 \mathrm{mmol} \mathrm{g}^{-1}$ (Fig. 7c, $n=65$ ). The PGD alternated between SYN and PRO (Fig. 7c). Climatological (May) and monthly (May 2004) PHYSAT data extracted from maps are in agreement.

In the central Pacific, there was an equatorward positive gradient of SST, Chl and DMS concentrations (Fig. 7a and b). PGD in this region and in the previous one were similar except near the equator where some NANO were detected (Fig. 7c). Although the DMS:Chl ratio was about twice as high a few degrees north of the equatorial divergence zone
(ED) than in the area of the north equatorial counter current (NECC) and the north equatorial current (NEC) $\left(4-15^{\circ} \mathrm{N}\right)$, overall the ratio was $2-3$ fold lower in the central than in the western Pacific.

In the eastern equatorial Pacific, water column density profiles indicated a shallow (10-25 m) mixed layer throughout the study region, and daily mixed layer growth irradiances were relatively high and invariant (Behrenfeld and Boss, 2006). Under such conditions, light-dependent physiological changes within the mixed layer are expected to be minimal. The gradients of SST were considerably higher than elsewhere in the equatorial Pacific (Fig. 7d). Density contours between $12^{\circ} \mathrm{N}$ and $8^{\circ} \mathrm{S}$ along the $95^{\circ} \mathrm{W}$ longitudinal line and $8^{\circ} \mathrm{S}$ and $8^{\circ} \mathrm{N}$ along the $110^{\circ} \mathrm{W}$ longitudinal line (see Fig. 2a and b in Behrenfeld and Boss, 2006) indicated that the ED was located between $0^{\circ}$ and $2^{\circ} \mathrm{S}$ at $95^{\circ} \mathrm{W}$ and between $1^{\circ} \mathrm{N}$ and $2^{\circ} \mathrm{S}$ at $110^{\circ} \mathrm{W}$. The convergent equatorial 

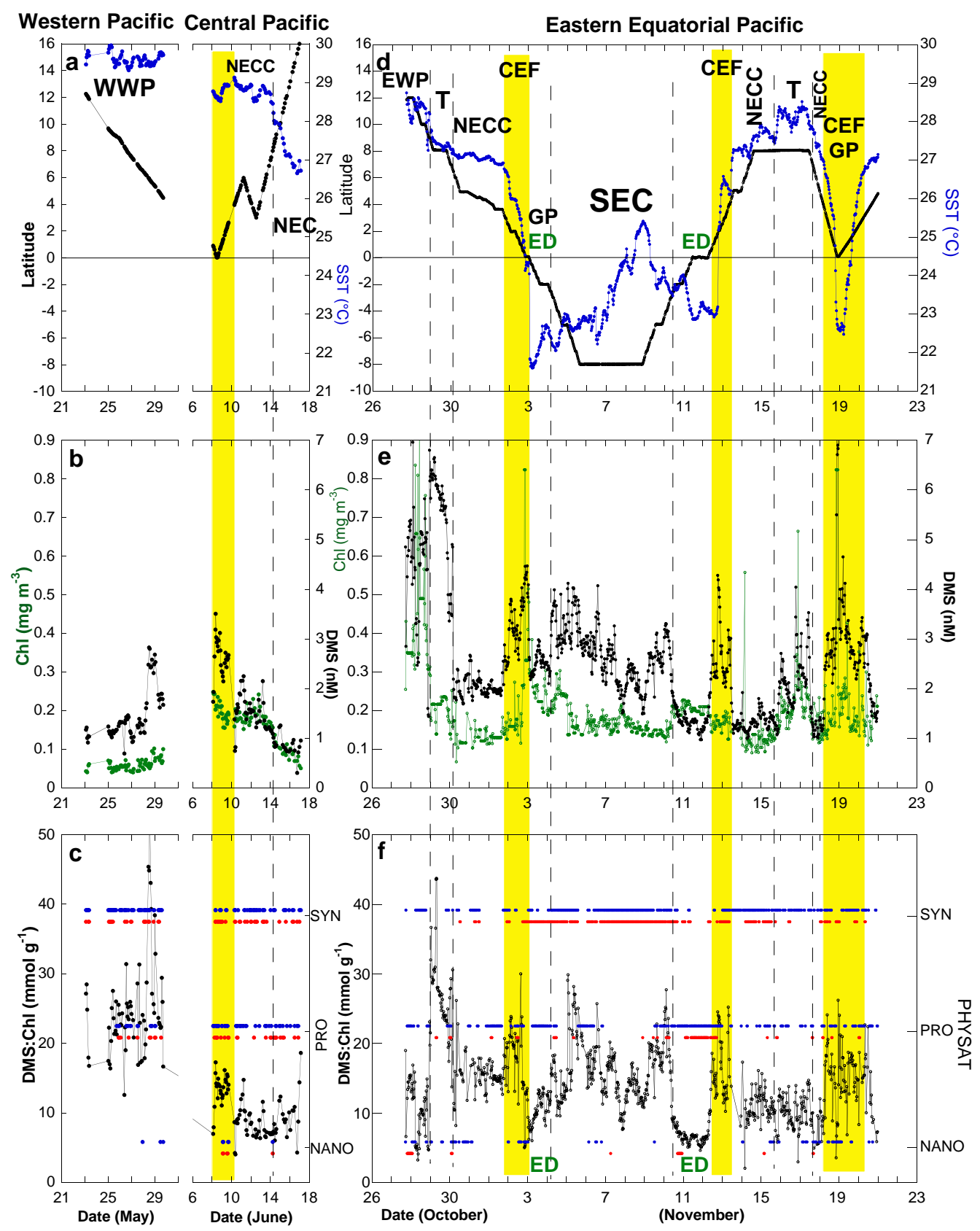

Fig. 7. Temporal variations of the following parameters in the western and central (left panels cruise CN-169) and eastern (right panels, cruise CN-148) Equatorial Pacific: (a,d) sea surface temperature (SST: ${ }^{\circ} \mathrm{C}$, in blue) and latitude (in black), (b, e) ocean color (Chl: $\mathrm{mg} \mathrm{m}^{-3}$, in green) and sea surface dimethylsulfide concentration (DMS: nM, in black), (c, f) DMS-to-Chl ratio (DMS:Chl, mmol g ${ }^{-1}$, in black) and monthly (red dots) and monthly climatological (blue dots) composites of phytoplankton group dominance. The yellow vertical bands correspond to the convergent equatorial front (CEF) where DMS accumulates. WWP: western warm pool, NEC: north equatorial current, EWP: eastern warm pool, NECC: north equatorial counter current, T: transition zone between EWP and NECC, GP: Galapagos plume, ED: equatorial divergence, SEC: south equatorial current.

front (CEF), which separates the warm and light waters of the NECC from the cooler and denser waters of the ED, is an area where DMS accumulates. The CEF was crossed 3 times during the cruise and DMS concentrations were systematically higher there than in the surrounding areas (Fig. 7e).
Water masses south of the equator (south equatorial current (SEC)) and north of the NECC (eastern warm pool (EWP) and the transition zone (T) between EWP and NECC), also displayed relatively high DMS levels. DMS concentrations were lowest in the ED. Since Chl concentrations were highest 
here, the DMS:Chl ratio (Fig. 7f) was very low. The PGD in the $\mathrm{ED}$ varied with longitude. At $95^{\circ} \mathrm{W}$, in the vicinity of the Galapagos Island (GP, date: 3 and 4 November), SYN dominated whereas far to the west $\left(110^{\circ} \mathrm{W}\right)$ PRO dominated (date: 11 and 12 November). Based on the climatology of PGD, PRO is more typical in the ED than SYN. SYN clearly dominated in the SEC both in November 2003 and in the climatology. The occurrence of NANO dominance is rare in the eastern Pacific in November 2003. Whatever the phytoplankton dominance is in the equatorial Pacific Ocean, mean DMS:Chl were markedly lower in ED than outside of this area (Tables 2 and 3). Mean DMS:Chl were not significantly higher in the presence of high DMSP producers (Table 3).

In the eastern North Pacific, the DMS:Chl increased from $5-12 \mathrm{mmolg}^{-1}$ at $20-25^{\circ} \mathrm{N}$ to $58-67 \mathrm{mmol} \mathrm{g}^{-1}$ at about $40^{\circ} \mathrm{N}$, but not steadily (Fig. 8c). The ratio followed the steady latitudinal decrease of SST (Fig. 8a) and was controlled by the DMS concentration (Fig. 8b). An increase in the DMS:Chl, also paralleling the SST but of smaller amplitude, was observed off the north American coast towards the center of the north Pacific at $45^{\circ} \mathrm{N}$. Between $40^{\circ} \mathrm{N}$ and $45^{\circ} \mathrm{N}$, the ratio dropped to low values when the vessel cut across a phytoplankton bloom. Unfortunately, no satellite data were available to produce PHYSAT dominances in this bloom area. Away from this bloom the PGD alternates between NANO, PRO and SYN. We find no significant difference in mean DMS:Chl between NANO and the other dominant group, or between high and low DMSP producers (Tables 2 and 3 ).

\subsubsection{North and South Atlantic Ocean}

The July 2007 cruise (CN-233) cut across cold (Fig. 8d) and unproductive (Fig. 8e) waters between $49^{\circ} \mathrm{W}$ and $53^{\circ} \mathrm{W}$ in the Labrador current. This is a transition area separating continental shelf waters (low salinities in the range 30.531.5) from the Atlantic subarctic waters (higher salinities in the range 34-35, Fig. 8c). The lowest DMS levels encountered on this cruise $(0.9-1.0 \mathrm{nM})$ were observed there. A major change in PGD took place at about $45^{\circ} \mathrm{W}$ (Fig. 8f). The southwestern sector was dominated by NANO and the DMS:Chl was in the range $2-10 \mathrm{mmol} \mathrm{g}^{-1}$. The northeastern sector displayed a larger range $\left(2-20 \mathrm{mmol} \mathrm{g}^{-1}\right)$ and less homogeneous PGD. The six PHYSAT categories were represented in this sector. However, the COC and PHAEO signals were recorded outside the area surveyed for DMS (Fig. 8f). The highest mean DMS:Chl were associated with SYN dominance (Table 2). However, when mean DMS:Chl were sorted between low and high DMSP producers, no significant difference was observed (Table 3).

The January 1999 cruise (CN-139) cut across a series of currents from $38^{\circ} \mathrm{N}$ to $30^{\circ} \mathrm{S}$ (Gulf Stream (GS), NECC, SEC and the Benguela current, Fig. 9a). It also crossed the Sargasso Sea, central waters of the north Atlantic subtropical gyre (SG), a westward extension of the Guinea Dome
(GD-ext), the equatorial divergence (ED) and the northern edge of the south Atlantic subtropical gyre before entering the more biologically productive areas off the African coast. The SG waters were poorer in Chl but about twice as rich in DMS than the Gulf Stream and the Sargasso Sea (Fig. 9b) yielding DMS:Chl up to $35 \mathrm{mmol} \mathrm{g}^{-1}$ (Fig. 9c). PGD in the SG was mainly PRO. In the northern and southern edges of the north Atlantic SG, PHYSAT dominances alternated between PRO and NANO. The January climatology of PGD depicts a slightly different picture in which PRO is not detected north of $25^{\circ} \mathrm{N}$ while PRO occurred up to $30^{\circ} \mathrm{N}$ in January 1999. NANO was the dominant phytoplankton group in the equatorial region from $10^{\circ} \mathrm{N}$ to $10^{\circ} \mathrm{S}$. This signature was associated with low DMS:Chl while ED was characterized by the lowest values $\left(3 \mathrm{mmol} \mathrm{g}^{-1}\right)$. The northern edge of the south Atlantic subtropical gyre was dominated by PRO with DMS:Chl ranging between 30 and $50 \mathrm{mmol} \mathrm{g}^{-1}$ (Fig. 9c). However, to the east the influence of the Benguela current (BC) was visible. DMS and Chl highs and lows alternated over short distances. While DMS concentrations were over $2 \mathrm{nM}$ everywhere, a clear positive gradient of Chl was observed towards the African coasts. The DMS:Chl ratio follows a similar trend since it is mainly controlled by Chl. The lowest ratios were observed in the core of the coastal upwelling (off Namibia) were SST dropped below $16^{\circ} \mathrm{C}$ (Fig. 9a). The PGD was NANO in the upwelling area. Offshore it alternated between NANO and PRO. SYN dominance was an extremely rare event in January along the track of the research vessel. We find no significant difference in mean DMS:Chl between NANO and SYN in the Atlantic away from ED and BC (Table 2). On the contrary, the difference between NANO and PRO was highly significant $(P<0.0001)$. The difference between high and low DMSP producers was also highly significant, but in this case the highest mean DMS:Chl was associated with the low DMSP producers (Table 3).

\section{Discussion}

The PHYSAT tool provides a way to trace the dominant phytoplankton populations from space at an unprecedented scale. However, the PHYSAT tool is not quantitative which is why it is used here in conjunction with relative changes in DMS (i.e. DMS normalized to Chl). Our surveys of DMS:Chl variations in three oceanic basins show that in the majority of cases the mean DMS:Chl ratios are not significantly higher when the dominant phytoplankton group belongs to the category of high DMSP producers (Table 3). This is especially true in the Atlantic Ocean but likely for different reasons listed hereafter. 

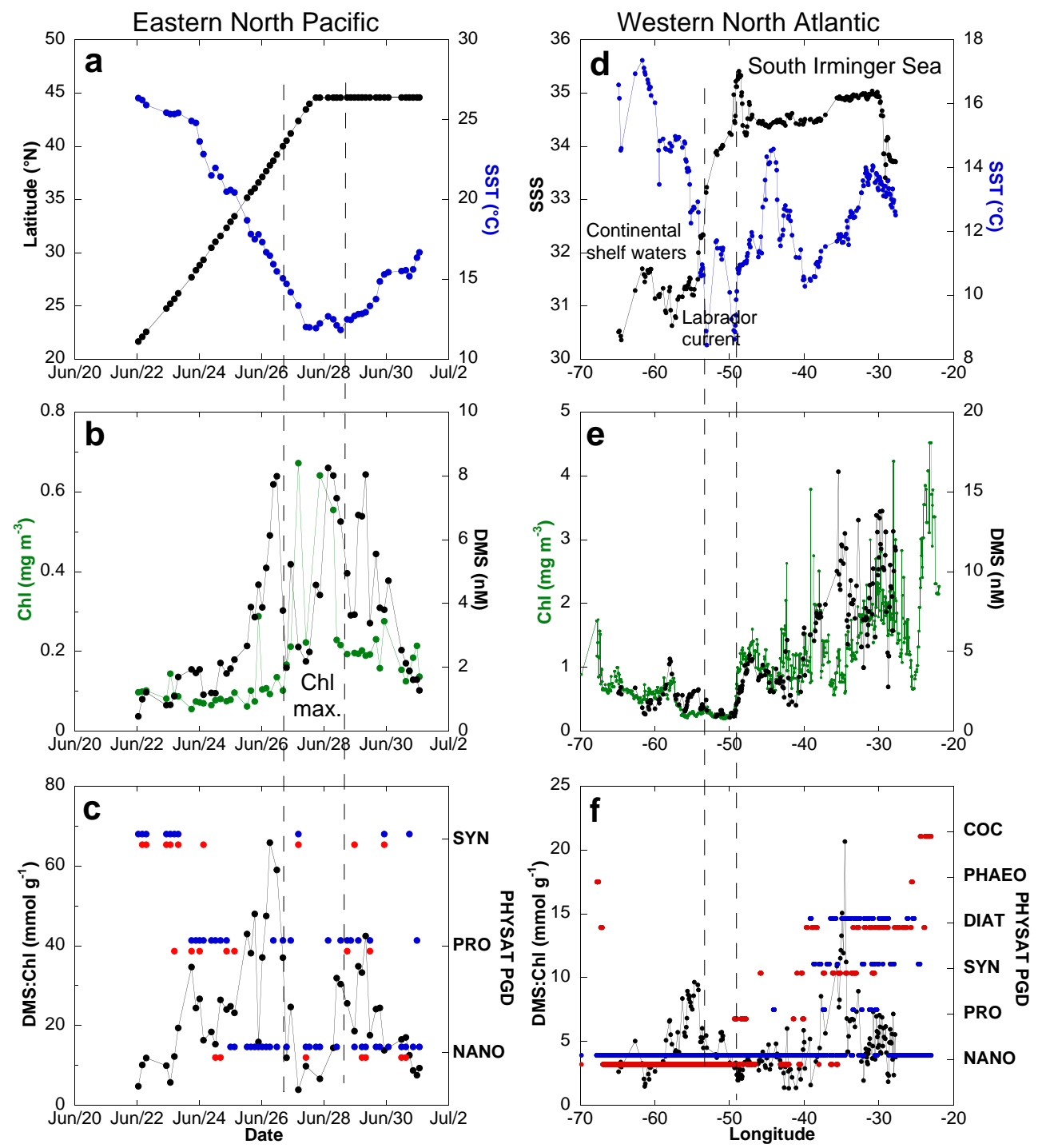

Fig. 8. Spatial or temporal distributions of the following parameters in the eastern North Pacific (left panels, cruise CN-169) and western North Atlantic (right panels, cruise $\mathrm{CN}-233$ ): (a, d) sea surface temperature (SST: ${ }^{\circ} \mathrm{C}$, in blue), latitude (in black), and sea surface salinity (PSU, in black) (b, e) ocean color (Chl: $\mathrm{mg} \mathrm{m}^{-3}$, in green) and sea surface dimethylsulfide concentration (DMS: nM, in black), (c, f) DMSto-Chl ratio (DMS:Chl, $\mathrm{mmol} \mathrm{g}^{-1}$, in black) and monthly (red dots) and monthly climatological (blue dots) composites of phytoplankton group dominance.

\subsection{PGD control on DMS: Chl variability in the Atlantic Ocean}

First, in the subtropical and tropical Atlantic Ocean away from the equatorial divergence and the Benguela current, data showed higher (ca. 40\%) mean DMS:Chl with PRO than with NANO dominance (Table 2). Moreover, DMS:Chl up to $35 \mathrm{mmol} \mathrm{g}^{-1}$ were observed in the North Atlantic subtropical gyre in winter (Fig. 9c). In the Sargasso Sea, where the dominant PHYSAT signature was NANO, the ratio ranged between 2 and $8 \mathrm{mmolg}^{-1}$ (Fig. 9c). Similar values were reported by Le Clainche et al. (2010) at the Bermuda Atlantic Time Series (BATS, $32^{\circ} \mathrm{N}-64^{\circ} \mathrm{W}$ ) site during win- tertime. This concentration range is very consistent with that reported by Scarratt et al. (2002) in the northwest Atlantic in May. Thus there appears to be a large difference in DMS:Chl between NANO and PRO dominated areas in winter in the North Atlantic subtropical gyre. This difference is most likely driven by the growth conditions and the physiological state of the sub-fraction of marine phytoplankton classified as non-dominant by PHYSAT because, according to culture experiments, prochlorophytes are poor DMS producers. The highest DMS:Chl in January 1999 coincided with the transition zone between the NANO and PRO dominated areas (Fig. 9c). The PHYSAT climatology suggests that the highest ratios coincide with the northern limit of 

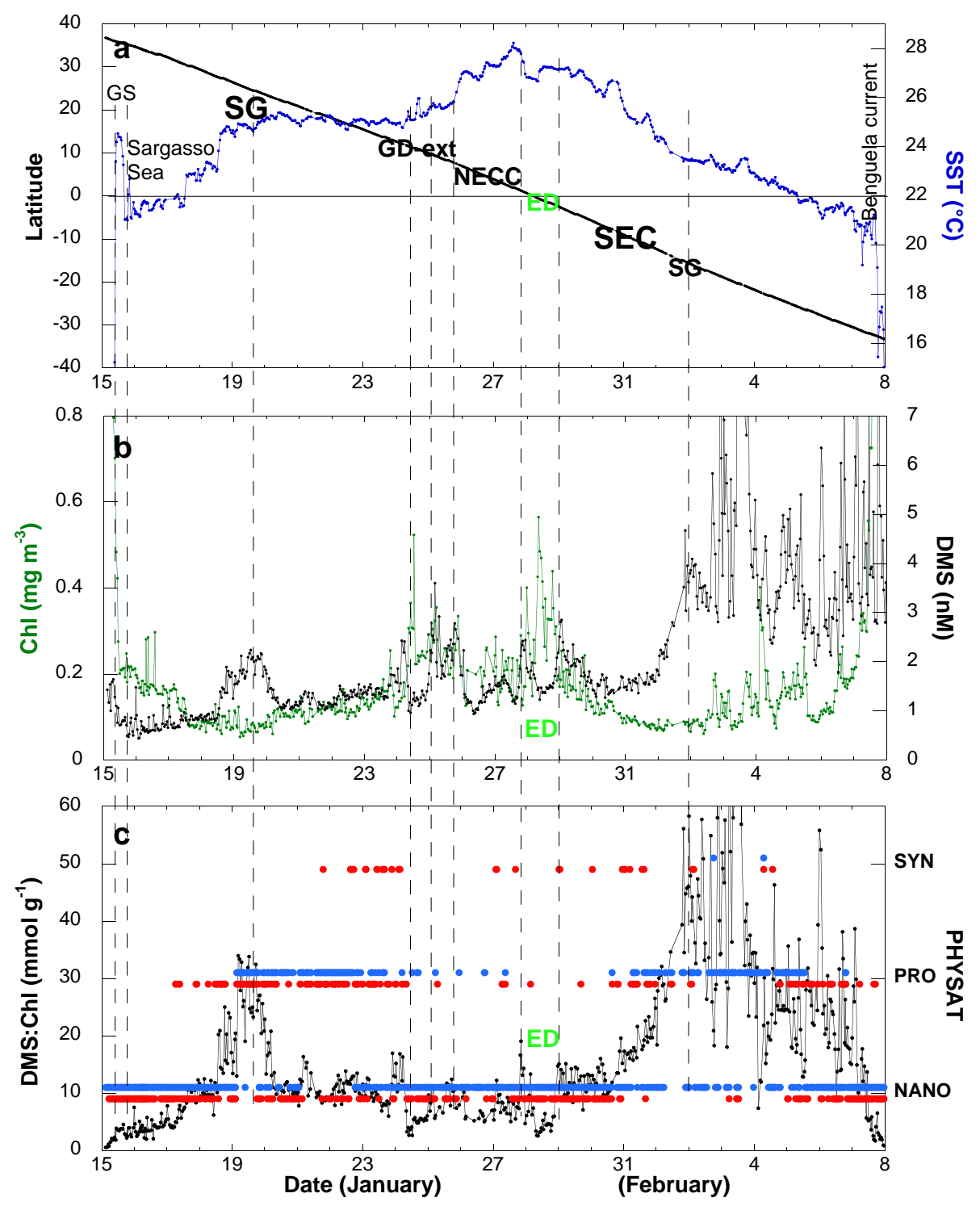

Fig. 9. Temporal variations of the following parameters in the north and south Atlantic Ocean (cruise CN-139): (a) sea surface temperature (SST: ${ }^{\circ} \mathrm{C}$, in blue) and latitude (in black), (b) ocean color (Chl: $\mathrm{mg} \mathrm{m}^{-3}$, in green) and sea surface dimethylsulfide concentration (DMS: $\mathrm{nM}$, in black), (c) DMS-to-Chl ratio (DMS:Chl, mmol g ${ }^{-1}$, in black) and monthly (red dots) and monthly climatological (blue dots) composites of phytoplankton group dominance. Chl levels over $0.8 \mathrm{mg} \mathrm{m}^{-3}$ were up to $2.7 \mathrm{mg} \mathrm{m}^{-3}$ and $9.1 \mathrm{mg} \mathrm{m}^{-3}$ off the North American and South African coasts, respectively. DMS levels over $7 \mathrm{nM}$ were up to $10.1 \mathrm{nM}$ and $11 \mathrm{nM}$ on 3 and 7 February, respectively. GS: Gulf stream, SG: subtropical gyre, GD-ext: Guinea dome extension, NECC: north equatorial counter current, ED: equatorial divergence, SEC: south equatorial current.

the PRO dominated areas (Fig. 9c). Thus, it is likely that the seasonal expansion towards the north of the PRO signature, as observed by Alvain et al. (2008) in the North Atlantic basin, traces that of oligotrophic systems and the well known associated relative accumulation of DMS that characterizes them (summer DMS paradox, Simó and Pedrós-Alió, 1999). The expansion of the PRO signature reaches the BATS station in summer where the relative accumulation of DMS over DMSP and Chl peaks (Dacey et al., 1998).
Second, the survey in the North Atlantic between the US coast and Iceland (CN-233) provides another illustration of the role of non-dominant phytoplankton in DMS production. Marandino et al. (2008) showed that the variability in seawater DMS levels was related to the satellite-derived distributions of coccoliths and, to a lesser extent, chlorophyll. However, PHYSAT did not detect COC dominance along the cruise track except in the vicinity of Iceland where, unfortunately, DMS was not measured (Fig. 8f). In the absence of other field measurements (e.g. cell enumeration), 
it is impossible to assess the relative contribution of coccolithophores to phytoplankton biomass during $\mathrm{CN}-233$. Nevertheless, the distribution of calcifying and silicifying phytoplankton in relation to environmental and biogeochemical parameters during the late stages of the 2005 north Atlantic spring bloom was investigated by Leblanc et al. (2009). The spatial distributions of fucoxanthin, biogenic silica, 19'hexanoyloxyfucoxanthin, particulate inorganic carbon (calcite) and peridinin concentrations, showed that diatoms dominated the phytoplankton community over prymnesiophytes, coccolithophores and autotrophic dinoflagellates in the Icelandic basin and shelf in early July. Hence, satellite products and ship-based observations in the western North Atlantic in summer suggest that coccolithophores account for a non-dominant fraction of phytoplankton. Thus, the mean DMS:Chl in DIAT dominated areas $\left(4.8 \pm 1.5 \mathrm{mmol} \mathrm{g}^{-1}\right.$, Table 2) could result from the production of DMS by coccolithophores (DMS vs. calcite relationship of Marandino et al., 2008 which supports earlier findings of Matrai and Keller, 1993) with diatoms responsible for the high chlorophyll levels. In the study of Vogt et al. (2008) carried out in a Norwegian Fjord, the phytoplankton bloom was also dominated by diatoms and prymnesiophytes, including lithed Emiliania huxleyi cells. At the highest DMS concentrations, the DMS:Chl were in the range $1-2 \mathrm{mmolg}^{-1}$. During the KEOPS study carried out over the Kerguelen Plateau, the iron-fertilized diatom bloom was high in Chl (ca. $1.3 \mathrm{mg} \mathrm{m}^{-3}$ ) but low in DMS (ca. $0.6 \mathrm{nM}$, Belviso et al., 2008). There, DMS:Chl were lower than $1 \mathrm{mmol} \mathrm{g}^{-1}$ because the DMS precursor (DMSP) was associated with a non-dominant fraction of phytoplankton made of small sized eucaryotes and single cells of Phaeocystis antarctica. In icefree waters of the Barents Sea (station IV) where diatoms accounted for about $80 \%$ of phytoplanktonic carbon biomass, the sea surface DMS:Chl was ca. $3.5 \mathrm{mmol} \mathrm{g}^{-1}$ (Matrai and Vernet, 1997). Consequently, a mean DMS:Chl equal to $4.9 \pm 2.2 \mathrm{mmol} \mathrm{g}^{-1}$ measured during $\mathrm{CN}-233$ (Table 3 ) is a relatively high number for an area dominated by low DMSP producers. Surface ocean DMS observations in COC dominated areas are definitely required to improve assessment of the ability of PHYSAT to predict temporal and spatial changes in DMS associated with COC blooms.

Third, approaching the coastal upwelling of southern Benguela, the gradient in DMS:Chl was negative in the onshore direction and PGD was NANO in a large majority of cases (Fig. 9c and Table 2). Although no DIAT dominance was found along cruise track, it is likely that diatoms accounted for a significant fraction of phytoplankton biomass, at least at inshore localities (Barlow et al., 2005), so that DIAT dominance could also be associated with low DMS:Chl. A similar decrease in DMS:Chl with diatom domination of the microplankton biomass was found off Mauritania at about $18^{\circ} \mathrm{N}$ (Franklin et al., 2009). Hence, PGD would not be the most important control on the variability of the DMS:Chl in the coastal upwelling of southern
Benguela. In the upwelling off the Moroccan coast, a transect through different plumes of upwelled waters and six longshore traverses of the same plume were carried out in September 1999 (Belviso et al., 2003). It was concluded that DMSP was homogeneously distributed amongst planktonic communities, because the sea surface concentration of total DMSP (tDMSP) was highly correlated with the total volume of suspended particles measured by an optical HIAC counter. The uniformity of the ratio between tDMSP and the volume of suspended particles in surface waters contrasted with the high variability of the DMS:Chl and DMS:tDMSP ratios. The ratios decreased in the onshore direction both in the plume and in an adjacent water mass. Marine $\mathrm{CO}_{2}$ levels suggested that the age of the upwelled waters was the main control on the variability of the ratios there, but not the phytoplankton community composition (Belviso et al., 2003).

Fourth, DMS:Chl were also especially low in the Equatorial Atlantic divergence zone were NANO dominance was observed (Fig. 9c and Table 2). The meridional distributions of DMS: $\mathrm{Chl}$ in a $10^{\circ}$-wide band around the equator, at $15-35^{\circ} \mathrm{W}$ in the Atlantic, $95^{\circ} \mathrm{W}$ and $110^{\circ} \mathrm{W}$ in the $\mathrm{Pa}-$ cific are shown in more detail in Fig. 10a and b, respectively. Abrupt decreases in DMS:Chl were observed when entering the equatorial divergence zone $\left(3 \mathrm{mmol} \mathrm{g}^{-1}\right.$ in the Atlantic and $5 \mathrm{mmol} \mathrm{g}^{-1}$ in the Pacific) from the north (NECC) or from the south (SEC). The latitudinal trends in DMS:Chl were similar in the two basins, yet PGD was different (SYN and PRO in the Pacific, NANO in the Atlantic).

We therefore conclude that DMS, Chl and PGD data gathered in the Atlantic Ocean provide no evidence that phytoplankton dominance determined from satellite measurements controls DMS:Chl variability in this basin.

\subsection{PGD control on DMS:Chl variability in the Pacific Ocean}

DMS:Chl variability in the Pacific Ocean is even less affected by PGD than in the Atlantic Ocean (Table 3). There is only about a 10\% difference in mean DMS:Chl between high and low DMSP producers in the equatorial Pacific away of the equatorial divergence zone. The decrease in DMS:Chl in the equatorial divergence is striking but it does not result from changes in phytoplankton group dominance (Table 3).

Dynamic models computing the meridional variations in phytoplankton C:Chl ratio as a function of temperature, light, nitrate and iron concentrations produce a reduced sea surface $\mathrm{C}: \mathrm{Chl}$ ratio in the eastern equatorial Pacific divergence zone (Wang et al., 2009). However, the meridional reduction in C:Chl ratio in November 2003 is moderate (about $50 \%$, X. W. Wang, personal communication, 2010) and results from the higher increase in $\mathrm{Chl}$ than in phytoplankton carbon in the equatorial divergence zone. The meridional reduction in DMS:Chl is considerably higher and results from low DMS values associated with high Chl values in the equatorial divergence zone. Observational evidence indicated that 

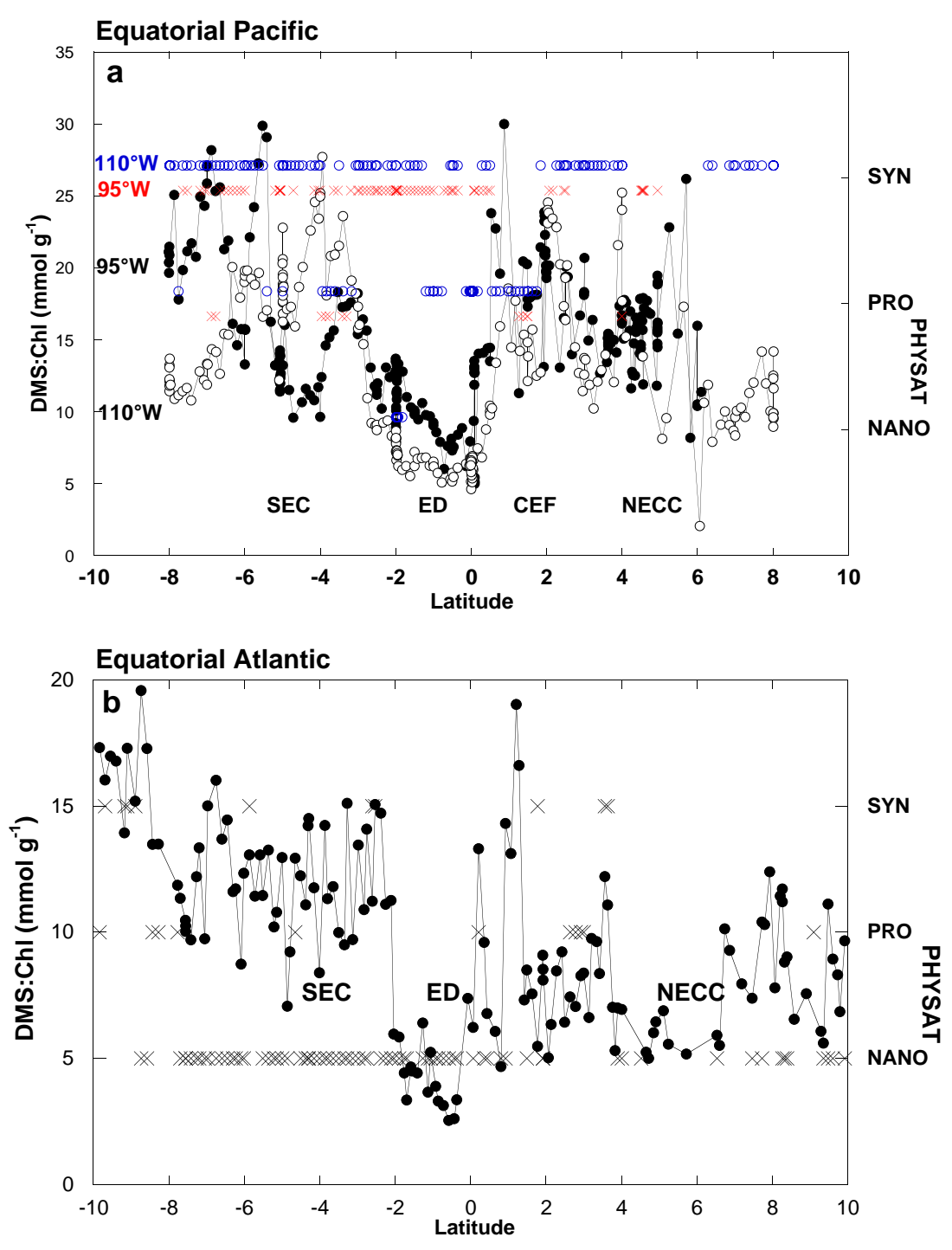

Fig. 10. (a) Latitudinal variations in DMS:Chl at $110^{\circ} \mathrm{W}$ and at $95^{\circ} \mathrm{W}$ (empty and full circles, respectively) and phytoplankton group dominance (blue circles and red crosses, respectively) in the Equatorial Pacific. (b) Same as (a) but in the Equatorial Atlantic between $15^{\circ}$ and $35^{\circ} \mathrm{W}$. NECC: north equatorial counter current, ED: equatorial divergence, CEF: convergent equatorial front, SEC: south equatorial current.

chlorophyll was functioning as a reliable measure of phytoplankton biomass in the eastern equatorial Pacific in November 2003 (Behrenfeld and Boss, 2006). Indeed, the particulate beam attenuation coefficient $\left(c_{\mathrm{p}}\right)$, a measure of suspended material mostly of phytoplanktonic origin, was extremely well correlated with fluorescence-based chlorophyll estimates (Fig. S3a, $r^{2}=0.93, n=8,880$ ) over the $6600 \mathrm{~km}$ transect. As Fig. S3c shows, $c_{\mathrm{p}}$ was less correlated with DMS than with $\mathrm{Chl}\left(r^{2}=0.19, n=424\right)$. However, when ED data is removed, the coefficient of determination of DMS vs. $c_{\mathrm{p}}$ markedly increases $\left(r^{2}=0.40, n=375\right.$, Fig. S3d). Therefore, ED data have a stronger impact on the DMS vs. $c_{\mathrm{p}}$ relationship than on that between $\mathrm{Chl}$ and $c_{\mathrm{p}}$. This provides inde- pendent support for the existence of a reduction in the ED of the DMS:Chl calculated from ocean color data. The highly significant linear relationship observed between total particulate organic carbon and $c_{\mathrm{p}}$ (see Fig. $4 \mathrm{~b}$ in Behrenfeld and Boss, 2006) suggests that community responses were sufficiently rapid to cause phytoplankton biomass changes to be well matched to changes in the other components comprising POC (bacteria, detritus and small grazers). Hence the link between DMS and ecological dynamics in the eastern equatorial Pacific in November 2003 is not as straightforward as that observed between $\mathrm{Chl}$ and ecological dynamics. Regardless of the phytoplankton dominance, mean DMS:Chl in the ED are roughly half than away from the 
ED (Table 3). This points toward a driving process that is not common to Chl and DMS. The eastern equatorial Pacific zone is characterized by a major plume of nutrient rich water located mostly south of the Equator. There, mean surface nitrate concentrations are over $5 \mu \mathrm{M}$ in the longitudinal band $95^{\circ} \mathrm{W}-110^{\circ} \mathrm{W}$ (Fiedler and Talley, 2006). Since nitrate photolysis is related to DMS photochemistry (Bouillon and Miller, 2004), it is possible that an enhancement in nitrate concentration increases the photochemical removal efficiency of DMS resulting in lower DMS concentrations in the surface ocean. Thus, the DMS dynamics in the eastern equatorial Pacific would be impacted by physical and chemical forcings more directly than by physiological and ecological processes. Because the latitudinal variations in DMS:Chl are roughly the same in the equatorial Atlantic and Pacific, it is suggested that the decoupling between DMS and phytoplankton biomass observed in the equatorial Pacific also operates in the equatorial Atlantic though we lack the supporting material (e.g. $c_{\mathrm{p}}$ measurements, indices of changes in algal physiology) in this latter case.

The Pacific convergent equatorial front (CEF) is a transition zone between the eastward-flowing NECC and the westward-flowing SEC. It is located north of the equator and, as our results show, is a place where gradients in DMS:Chl are especially steep. Moreover, in the central Pacific (at $140^{\circ} \mathrm{W}$ ) where SST gradients were considerably weaker than at $95^{\circ} \mathrm{W}$ and $110^{\circ} \mathrm{W}$ (Fig. 7a), the ratio still rose markedly between $0^{\circ}$ and $2^{\circ} \mathrm{N}$ (Fig. 7c). It is known that the CEF accumulates buoyant organic material that can be seen from space and attracts foraging seabirds and other trophic level species (Pennington et al., 2006 and references therein). Clearly, DMS accumulates there too. This is consistent with the idea that DMS serves as a foraging cue for seabirds (Nevitt et al., 1995). When zooplankton prey upon phytoplankton rich in DMSP and in DMSP-lyases, part of the particulate material is released to solution and converted to DMS. Nanoeucaryotes are richer in DMSP and lyases than cyanophytes and prochlorophytes. This is true on a per cell basis, or when DMSP is normalized to cell carbon or chlorophyll (Stefels et al., 2007). Because PHYSAT dominance in the equatorial Atlantic is NANO and because chlorophyll levels are slightly higher in the Atlantic than in the Pacific, higher phytoplankton production of DMS is expected in the Atlantic than in the Pacific. Therefore, the Atlantic should display higher DMS levels than the Pacific. Definitely, this is not the case in equatorial waters as the comparison of Fig. 7e and Fig. $9 \mathrm{~b}$ shows. Consequently, phytoplankton dominance does not control the concentration of DMS in equatorial waters neither in absolute nor in relative (when normalized to $\mathrm{Chl}$ concentration). It appears that the upper ocean dynamics near the equator is important in two aspects: upwelling areas are not favorable for DMS accumulation whereas convergent fronts are important.
Since the equatorial Pacific Ocean is subject to large interannual variations in upper ocean dynamics during El NiñoSouthern Oscillation (ENSO) cycles, it is expected that the spatio-temporal DMS distribution will change accordingly. Indeed, there appears to be large changes in DMS in the vicinity of the equatorial divergence during El Niño and La Niña events as shown from historical data gathered in Fig. S4. During non El-Niño events (La Niña or transition phase), data collected between the equator and $5^{\circ} \mathrm{N}$, at the position of the convergent front, show an accumulation of DMS of varying intensity $(4-11 \mathrm{nM})$ in the central $\left(140^{\circ} \mathrm{W}\right.$, Fig. S4a) and eastern $\left(110^{\circ} \mathrm{W}\right.$, Fig. S4b) Equatorial Pacific. This local accumulation apparently disappears during ElNiño events (1.2-2.3 nM) suggesting a relationship between ENSO cycles and the DMS distribution. However, the DMS loss at the location of the convergent equatorial front during El-Niño events can be partly compensated by an increase in DMS in the area of the equatorial divergence at $110^{\circ} \mathrm{W}$ (Fig. S4b, April 1983). No such compensation is observed at $140^{\circ} \mathrm{W}$ in March 1992 (Fig. S4a). Hence, the changes in physical features associated with ENSO events appear to have a stronger effect on the concentration of DMS at the local scale than over large distances across the Equatorial Pacific (Bates and Quinn, 1997). These results provide after Wong et al. (2006) a new example of how climate fluctuations, through altering the physical properties of the upper ocean, may influence the DMS concentrations in the open ocean. SeaWiFS and PHYSAT surveys show a marked drop in phytoplankton biomass and a shift from SYN to NANO in the equatorial Pacific during El Niño events (Masotti et al., 2010). Since DMS concentrations and the phytoplankton biomass drop simultaneously, the ratio of both is expected to remain roughly constant. Therefore, a shift from SYN to NANO during El Niño events would not be expected to effect the DMS:Chl ratio. This is consistent with our observations which show no significant difference $(P=0.148)$ in mean sea surface DMS:Chl exhibiting SYN $\left(14.6 \pm 5.0 \mathrm{mmol} \mathrm{g}^{-1}\right)$ and NANO dominances $\left(13.7 \pm 2.7 \mathrm{mmol} \mathrm{g}^{-1}\right.$, Table 2$)$.

\subsection{PGD control on DMS: Chl variability in the Austral Ocean}

In the Pacific sector of the Southern Ocean, there is about a 20\% enhancement in the mean DMS:Chl in areas where low DMSP producers predominate (Table 3). Conversely, in the Indian sector of the Southern Ocean, mean DMS:Chl with SYN and PRO are about one half that of values with NANO or PHAEO dominances (Table 2), or when DMS:Chl data is sorted by high or low DMSP producers (Table 3). Although this trend is consistent with our current understanding of DMSP production by phytoplankton, culture studies have shown considerably higher differences than a factor of two between cyanophytes and haptophytes (e.g. a difference of 3 orders of magnitude is reported by Stefels et al. (2007) in terms of DMSP normalized to Chl). Model results also show 
a much higher contrast in DMS:Chl when phytoplankton is sorted in categories of low and high DMSP producers, especially in the high latitudes in summer when NANO and/or COC bloom (Fig. S1a and b).

\section{Conclusion and perspectives}

The PHYSAT tool allows the characterization at the global scale of dominant phytoplankton groups. It was applied for the first time to the marine sulfur cycle in an effort to assess whether variability in the DMS:Chl ratio is consistent with the distribution of dominant phytoplankton groups as determined from space. Based on this survey, the Indian sector of the Southern Ocean is the only region where the spatial variations in the DMS:Chl ratio appear to be consistent with the generally accepted classification between high and low DMSP-producing phytoplankton. There, the ratios in SYNdominated areas are roughly one half of those in NANO- and PHAEO-dominated areas. Overall, our results indicate that phytoplankton group dominance is not the primary controller of DMS dynamics over most of the oceans. We therefore conclude that ocean color sensor measurements of Chl concentrations and dominant phytoplankton groups can not be used to predict global fields of DMS.

The spatial resolution of the PHYSAT records will improve markedly in the near future. The new PHYSAT products will display 4 to $9 \mathrm{~km}$ horizontal resolution. The temporal resolution should be also improved (daily observation matchup) to investigate times when the succession of phytoplankton groups is happening quickly. This will offer a new opportunity to investigate the effect of phytoplankton dominance on the small-scale distribution of DMS especially in coastal waters. Moreover, future remote sensing studies should focus on characterization of the total phytoplankton biomass, the non-dominant component of phytoplankton assemblages, the physiological state and the development stages of phytoplankton, and the environmental factors controlling DMS removal processes. For example, particulate backscattering and calcite products, phytoplankton fluorescence, colored dissolved organic material and irradiance below clouds would be useful. Bacteria are important organisms in DMS biogeochemistry but, unfortunately, the assessment of bacterial biomass and activity is not yet possible from remote sensing.

\section{Supplementary material related to this article is available online at: http://www.biogeosciences.net/7/3215/2010/ bg-7-3215-2010-supplement.pdf.}

Acknowledgements. We gratefully acknowledge scientists, officers and crew aboard R. V. Marion Dufresne for their help during the cruise KEOPS. In particular, we extend our thanks to the project leader, S. Blain, and to the chief scientist, B. Quéguiner. The authors thank NASA/GSFC/DAAC for providing access to daily L3 SeaWiFS binned products. We also thank Patrick Brockmann for assistance in the data management and M. J. Behrenfeld and E. Boss for making beam attenuation coefficient $\left(c_{\mathrm{p}}\right)$ data available on line at http://www.science.oregonstate.edu/ocean. productivity/field.data.fl.online.php. We express our special thanks to $\mathrm{X}$. W. Wang who computed for us the spatial distribution of the sea surface $\mathrm{C}: \mathrm{Chl}$ ratio in the eastern Equatorial Pacific for November 2003. We thank also L. Bopp and M. Vogt for making PISCES and PlankTOM5 modeling data available for us. We thank the two anonymous reviewers for their constructive comments and suggestions to help improving the manuscript. This is LSCE contribution number 4056.

Edited by: T. J. Battin

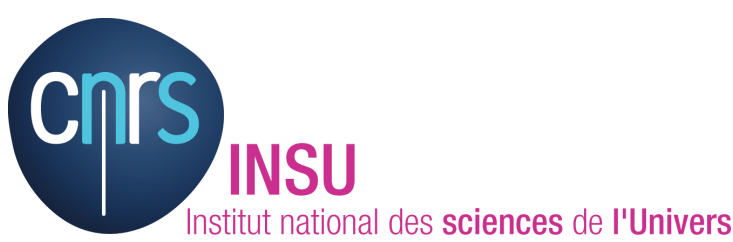

The publication of this article is financed by CNRS-INSU.

\section{References}

Alvain, S., Moulin, C., Dandonneau, Y., and Bréon, F. M.: Remote sensing of phytoplankton groups in case 1 waters from global SeaWiFS imagery, Deep Sea-Res. Pt. I, 52, 1989-2004, 2005.

Alvain, S., Moulin, C., Dandonneau, Y., and Loisel, H.: Seasonal distribution and succession of dominant phytoplankton groups in the global ocean: A satellite view, Global Biogeochem. Cy., 22, GB3001, doi:10.1029/2007GB003154, 2008

Barlow, R., Sessions, H., Balarin, M., Weeks, S., Whittle C., and Hutchings, L.: Seasonal variation in phytoplankton in the southern Benguela: pigment indices and ocean colour, Afr. J. Mar. Sci., 27(1), 275-287, 2005.

Bates, T. S., Cline, J. D., Gammon, R. H., and Kelly-Hansen, S. R.: Regional and seasonal variations in the flux of oceanic dimethylsulfide to the atmosphere, J. Geophys. Res., 92, 2930-2938, 1987.

Bates, T. S. and Quinn, P. K.: Dimethylsulfide (DMS) in the equatorial Pacific Ocean (1982 to 1996): Evidence of a climate feedback?, Geophys. Res. Lett., 24(8), 861-864, doi:10.1029/97GL00784, 1997.

Bates, T. S., Quinn, P. K., Coffman, D. J., Johnson, J. E., Miler, T. L., Covert, D. S., Wiedensohler, A., Leinert, S., Nowak, A., and Neusüss, C.: Regional physical and chemical properties of the marine boundary layer aerosol across the Atlantic during Aerosols99: An overview, J. Geophys. Res., 106, 20767-20782, 2001.

Belviso, S., Sciandra, A., and Copin-Montégut, C.: Mesoscale features of surface water DMSP and DMS concentrations in the Atlantic Ocean off Morocco and in the Mediterranean Sea, DeepSea Res. Pt. I, 50(4), 543-555, 2003.

Belviso, S., Bopp, L., Moulin, C., Orr, J. C., Anderson, T. R., Chu, S., Elliott, S., Maltrud, M. E., and Simo, R.: Comparison of 
global maps of sea surface dimethylsulfide, Global Biogeochem. Cy., 18, GB3013, doi:10.1029/2003GB002193, 2004.

Belviso, S., Bopp, L., Mosseri, J., Tedetti, M., Garcia, N., Griffiths, B., Joux, F., Obernosterer, I., Uitz, J., and Veldhuis, M. J. W.: Effect of natural iron fertilisation on the distribution of DMS and DMSP in the Indian sector of the Southern Ocean, Deep-Sea Res. Pt. II, 55(5-7), 893-900, 2008.

Behrenfeld, M. J. and Boss, E.: Beam attenuation and chlorophyll concentration as alternative optical indices of phytoplankton biomass, J. Mar. Res., 64, 431-451, 2006.

Bopp, L., Aumont, O., Belviso, S., and Monfray, P.: Potential impact of climate change on marine dimethylsulfide (DMS) emissions, Tellus B, 55, 11-22, 2003.

Bopp, L., Aumont, O., Belviso, S., and Blain, S.: Modeling the effect of iron fertilization on dimethylsulfide emissions in the Southern Ocean, Deep-Sea Res. Pt. II, 55(5-7), 901-912, 2008.

Bouillon, R.-C. and Miller, W. L.: Determination of apparent quantum yield spectra of DMS photodegradation in an in situ ironinduced Northeast Pacific Ocean bloom, Geophys. Res. Lett., 31, L06310, doi:10.1029/2004GL019536, 2004.

Brown, C. W. and Yoder, J. A.: Coccolithophorid blooms in the global ocean, J. Geophys. Res., 99, 7467-7482, 1994.

Bucciarelli, E. and Sunda, W. G.: Influence of $\mathrm{CO}_{2}$, nitrate, phosphate, and silicate limitation on intracellular dimethylsulfoniopropionate in batch cultures of the coastal diatom Thalassiosira pseudonana, Limnol. Oceanogr., 48, 2256-2265, 2003.

Carslaw, K. S., Boucher, O., Spracklen, D. V., Mann, G. W., Rae, J. G. L., Woodward, S., and Kulmala, M.: A review of natural aerosol interactions and feedbacks within the Earth system, Atmos. Chem. Phys., 10, 1701-1737, doi:10.5194/acp-10-17012010, 2010.

Charlson, R. J., Lovelock, J. E, Andreae, M. O., and Warren, S. G.: Oceanic phytoplankton, atmospheric sulfur, cloud albedo and climate, Nature, 326, 655-661, 1987.

Colomb, A., Gros, V., Alvain, S., Sarda-Esteve, R., Bonsang, B., Moulin, C., Klüpfel T., and Williams, J.: Variation of atmospheric volatile organic compounds over the Southern Indian Ocean (30-49 ${ }^{\circ}$ S), Environ. Chem., 6, 70-82, doi:10.1071/EN08072, 2009.

Dacey, J. W. H., Howse, F. A., Michaels, A. F., and Wakeham, S. G.: Temporal variability of dimethylsulfide and dimethylsulfoniopropionate in the Sargasso Sea, Deep-Sea Res. Pt. I, 45, 2085 2104, 1998.

Fiedler, P. C. and Talley, L. D.: Hydrography of the eastern tropical Pacific: a review, Prog. Oceanogr., 69, 143-180, 2006.

Franklin, D. J., Poulton, A. J., Steinke, M., Young, J., Peeken, I., and Malin, G.: Dimethyl-sulphide, DMSP-lyase activity and microplankton community structure inside and outside of the Mauritanian upwelling, Prog. Oceanogr., 83, 134-142, 2009.

Goffart, A., Catalano, G., and Hecq, J. H.: Factors controlling the distribution of diatoms and Phaeocystis in the Ross Sea, J. Marine Syst., 27, 161-175, 2000.

Halloran, P. R., Bell, T. G., and Totterdell, I. J.: Can we trust empirical marine DMS parameterisations within projections of future climate?, Biogeosciences, 7, 1645-1656, doi:10.5194/bg-71645-2010, 2010.

Keller, M. D., Bellows, W. K., and Guillard, R. R. L.: Dimethylsulfide production in marine phytoplankton, in: Biogenic sulfur in the environment, edited by: Saltzman, E. S. and Cooper, W. J.,
American Chemical Society, Washington DC, 167-182, 1989.

Kasamatsu, N., Kawaguchi, S., Watanabe, S., Odate, T., and Fukuchi, M.: Possible impacts of zooplankton grazing on dimethylsulfide production in the Antarctic Ocean, Can. J. Fish. Aquat. Sci, 61, 736-743, 2004.

Kettle, A. J., Andreae, M. O., Amouroux, D., Andreae, T. W., Bates, T. S., Berresheim, H., Bingemer, H., Boniforti, R., Curran, M. A. J., DeTullio, G. R., Helas, G., Jones, G. B., Keller, M. D., Kiene, R. P. , Leck, C., Levasseur, M., Maspero, M., Matrai, P., McTaggart, A. R., Mihalopoulos, N., Nguyen, B. C., Novo, A., Putaud, J. P., Rapsomanikis, S., Roberts, G., Schebeske, G., Sharma, S., Simo, R., Staubes, R., Turner S., and Uher, G.: A global database of sea surface dimethylsulfide (DMS) measurements and a simple model to predict sea surface DMS as a function of latitude, longitude and month, Global Biogeochem. Cy., 13, 399-444, 1999.

Kiene, R. P., Linn, L. J., and Bruton, J. A.: New and important roles for DMSP in marine microbial communities, J. Sea Res. 43, 209-224, 2000.

Leblanc, K., Hare, C. E., Feng, Y., Berg, G. M., DiTullio, G. R., Neeley, A., Benner, I., Sprengel, C., Beck, A., Sanudo-Wilhelmy, S. A., Passow, U., Klinck, K., Rowe, J. M., Wilhelm, S. W., Brown, C. W., and Hutchins, D. A.: Distribution of calcifying and silicifying phytoplankton in relation to environmental and biogeochemical parameters during the late stages of the 2005 North East Atlantic Spring Bloom, Biogeosciences, 6, 21552179, doi:10.5194/bg-6-2155-2009, 2009.

Le Clainche, Y., Vézina, A., Levasseur, M., Cropp, R., Gunson, J., Vallina, S., Vogt, M., Lancelot, C., Allen, I., Archer, S., Bopp, L., Deal, C., Elliott, S., Jin, M., Malin, G., Schoemann, V., Simo, R., Six, K., and Stefels, J.: A first appraisal of prognostic ocean DMS models and prospects for their use in climatic models, Global Biogeochem. Cy., 24, GB3021, doi:10.1029/2009GB003721, 2010.

Malin, G., Turner, S., Liss, P., Holligan, P., and Harbour, D.: Dimethylsulphide and dimethylsulfoniopropionate in the Northeast Atlantic during the summer coccolithophore bloom, DeepSea Res. Pt. I, 40, 1487-1508, 1993.

Marandino, C. A., De Bruyn, W. J., Miller, S. D., and Saltzman, E. S.: Eddy correlation measurements of the air/sea flux of dimethylsulfide over the North Pacific Ocean, J. Geophys. Res., 112, D03301, doi:10.1029/2006JD007293, 2007.

Marandino, C. A., De Bruyn, W. J., Miller, S. D., and Saltzman, E. S.: DMS air/sea flux and gas transfer coefficients from the North Atlantic summertime coccolithophore bloom, Geophys. Res. Letts., 35, L23812, doi:10.1029/2007GL036370, 2008.

Masotti, I., Moulin, C., Alvain, S., Bopp, L., Tagliabue, A., and Antoine, D.: Large-scale shifts in phytoplankton groups in the Equatorial Pacific during ENSO cycles, Biogeosciences Discuss., 7, 2523-2548, doi:10.5194/bgd-7-2523-2010, 2010.

Matrai, P. A. and Keller, M. D.: Dimethylsulfide in a large-scale coccolithophore bloom in the Gulf of Maine, Cont. Shelf Res., 13, 831-843, 1993.

Matrai, P. A. and Vernet, M.: Dynamics of the vernal bloom in the marginal ice zone of the Barents Sea: Dimethylsulfide and dimethylsulfoniopropionate budgets, J. Geophys. Res., 102, 22965-22979, 1997.

Nevitt, G. A., Veit, R. R., and Kareiva, P.: Dimethyl sulphide as a foraging cue for Antarctic Procellariiform seabirds, Nature, 376, 
680-682, 1995.

Park, Y.-H., Roquet, F., Durand, I., and Fuda, J. L.: Large-scale circulation over and around the northern kerguelen Plateau, DeepSea Res. Pt. II, 55, 566-581, 2008.

Pennington, J. T., Mahoney, K. L., Kuwahara, V. S., Kolber, D. D., Calienes, R., and Chavez, F. P.: Primary production in the eastern tropical Pacific: A review, Prog. Oceanogr. 69, 285-317, 2006.

Scarratt, M. G., Levasseur, M., Michaud, S., Cantin, G., Gosselin, M., and de Mora, S. J.; Influence of phytoplankton taxonomic profile on the distribution of dimethylsulfide and dimethylsulfoniopropionate in the northwest Atlantic, Mar. Ecol.-Prog. Ser., 244, 49-61, 2002.

Sciare, J., Mihalopoulos, N., and Nguyen, B. C.: Summertime seawater concentrations of dimethylsulfide in the Western Indian Ocean: Reconciliation of fluxes and spatial variability with longterm atmospheric observations, J. Atmos. Chem., 32, 357-373, 1999.

Simó, R. and Pedrós-Alió, C.: Role of vertical mixing in controlling the oceanic production of dimethyl sulphide, Nature, 402, 396399, 1999.

Smith, W. O., Dennett, Jr., M. R., Mathot, S., and Caron, D. A.: The temporal dynamics of the flagellated and colonial stages of Phaeocystis antarctica in the Ross Sea, Deep Sea-Res. Pt. II, 50, 605-618, 2003.

Stefels, J., Steinke, M., Turner, S., Malin, G., and Belviso, S.: Environmental constraints on the production and removal of the climatically active gas dimethylsulfide (DMS) and implications for ecosystem modeling, Biogeochemistry, 83, 245-275, doi:10.1007/s10533-007-9091-5, 2007.

Sunda, W. G., Hardison, R., Kiene, R. P., Bucciarelli, E., and Harada, H.: The effect of nitrogen limitation on cellular DMSP and DMS release in marine phytoplankton: climate feedback implications, Aquat. Sci., 69, 341-351, 2007.
Tortell, P. D. and Long, M. C.: Spatial and temporal variability of biogenic gases during the Southern Ocean spring bloom, Geophys. Res. Lett., 36, L01603, doi:10.1029/2008GL035819, 2009.

Turner, S. M., Malin, G., Liss, P. S., Harbour, D. S., and Holligan, P. M.: The seasonal variation of dimethyl sulfide and dimethylsulfoniopropionate concentrations in nearshore waters, Limnol. Oceanogr., 33, 364-375, 1988.

Vallina, S. M., Simo, R., and Manizza, M.: Weak response of oceanic dimethylsulfide to upper mixing shoaling induced by global warming, Proc. Nat. Acad. Sci., 104(41), 16004-16009, doi:10.1073/pnas.0700843104, 2007.

Vogt, M., Steinke, M., Turner, S., Paulino, A., Meyerhöfer, M., Riebesell, U., LeQuéré, C., and Liss, P.: Dynamics of dimethylsulphoniopropionate and dimethylsulphide under different $\mathrm{CO}_{2}$ concentrations during a mesocosm experiment, Biogeosciences, 5, 407-419, doi:10.5194/bg-5-407-2008, 2008.

Vogt, M. and Liss, P.: Dimethylsulphide, clouds and climate, in: Surface ocean lower atmosphere processes, edited by: Le Quéré, C. and Saltzman, E., Geophysical Monograph Series, Vol. 187, American Geophysical Union, ISBN 978-0-87590-477-1, 2009.

Vogt, M., Vallina, S. M., Buitenhuis, E. T., Bopp, L., and Le Quéré, C.: Simulating dimethylsulphide seasonality with the Dynamic Green Ocean Model PlankTOM5, J. Geophys. Res., 115, C06021, doi:10.1029/2009JC005529, 2010.

Wang, X. W., Le Borgne, R., Murtugudde, R., Busalacchi, A. J., and Behrenfeld, M.: Spatial and temporal variability of the phytoplankton carbon to chlorophyll ratio in the equatorial Pacific: a basin-scale modeling study, J. Geophys. Res., 114, C07008, doi:10.1029/2008JC004942, 2009.

Wong, C. S., Wong, S. E., Peña, A., and Levasseur, M.: Climatic effect on DMS producers in the NE sub-arctic Pacific, Tellus, 58B, 319-326, 2006. 